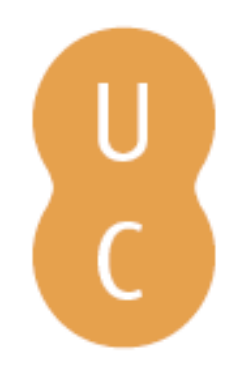

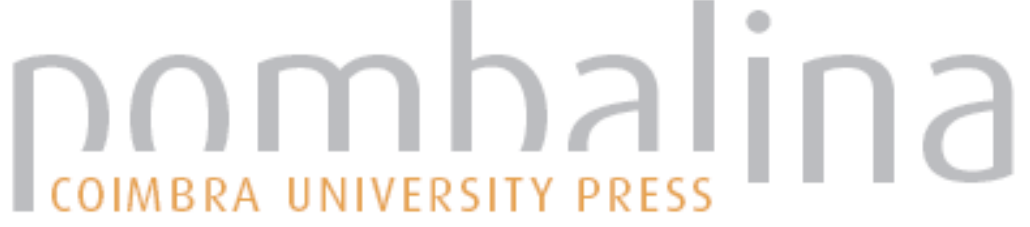

\section{Transição e ditadura em Portugal nos primórdios do século XX}

Autor(es): $\quad$ Catroga, Fernando

Publicado por: Imprensa da Universidade de Coimbra

URL

persistente: URI:http://hdl.handle.net/10316.2/31331

DOI: $\quad$ DOI:http://dx.doi.org/10.14195/978-989-26-0465-7_2

Accessed : $\quad$ 26-Apr-2023 04:11:54

A navegação consulta e descarregamento dos títulos inseridos nas Bibliotecas Digitais UC Digitalis, UC Pombalina e UC Impactum, pressupõem a aceitação plena e sem reservas dos Termos e Condições de Uso destas Bibliotecas Digitais, disponíveis em https://digitalis.uc.pt/pt-pt/termos.

Conforme exposto nos referidos Termos e Condições de Uso, o descarregamento de títulos de acesso restrito requer uma licença válida de autorização devendo o utilizador aceder ao(s) documento(s) a partir de um endereço de IP da instituição detentora da supramencionada licença.

Ao utilizador é apenas permitido o descarregamento para uso pessoal, pelo que o emprego do(s) título(s) descarregado(s) para outro fim, designadamente comercial, carece de autorização do respetivo autor ou editor da obra.

Na medida em que todas as obras da UC Digitalis se encontram protegidas pelo Código do Direito de Autor e Direitos Conexos e demais legislação aplicável, toda a cópia, parcial ou total, deste documento, nos casos em que é legalmente admitida, deverá conter ou fazer-se acompanhar por este aviso.

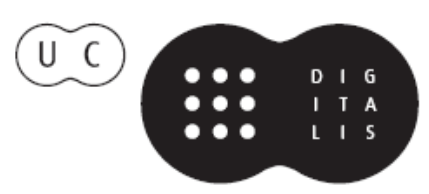




\section{R U I \\ C U N H A \\ M A R T I N S}

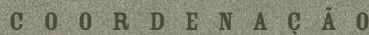

\section{PORTUGAL}
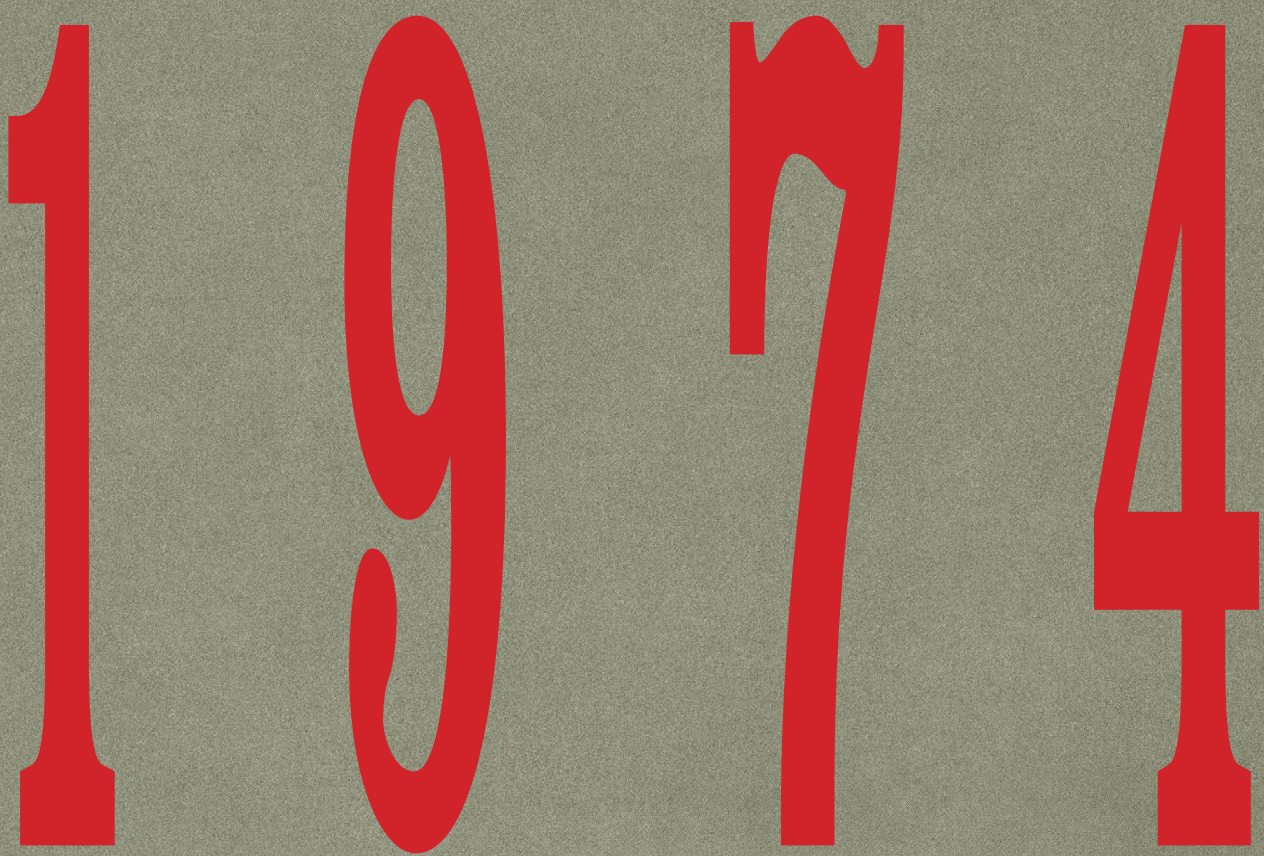

Transiçấo

PoLitica EM

Perspectiva

HISTÓRICA

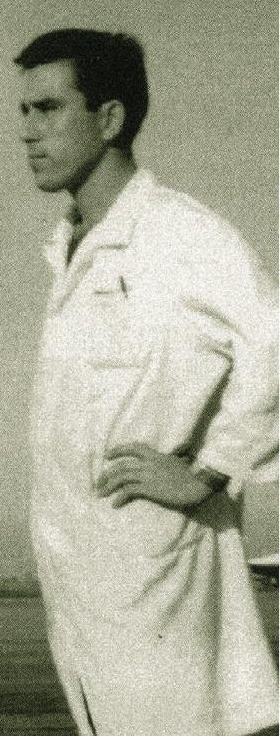




\section{Transição E Ditadura em PORTUGAL NOS PRIMÓRDIOS DO SÉCULO XX}

FERNANDO CATROGA ${ }^{13}$

Nos dois últimos séculos, o uso do vocábulo "transição" ganhou uma grande voga devido à crescente hegemonia da concepção irreversível do tempo, na qual o presente, ou, pelo menos, o passado menos antigo, aparece não só como momento de crise ou de decadência, mas também como passagem para um futuro acreditado como previsível. Por isso, o seu significado também implica o entendimento da história como um iter, ideia antiga que Santo Agostinho cristianizou, para sujeitar a condição de homo viator a um destino transcendente e escatológico. Porém, a modernidade centrá-la-á no próprio devir, subordinando-o a periodizações seleccionadas para marcar "idades", "eras", "etapas" na progressão qualitativa do tempo histórico. Nunca, como a partir daí, o homem se sentiu viajante do caminho que ele mesmo quer construir. E, como estar em trânsito exige saber de onde se vem e para onde se vai, a história foi desenhada como um percurso qualitativo, onde a transição, se transportava consigo o novo, também não pretendia romper, em absoluto, nem com a herança que almejava superar, nem com a ideia de consumação ou de fim da história ínsita à sua própria diacronia.

Não surpreende, assim, que ela apareça propulsada pela "revolução", termo que se popularizou, sobretudo, após 1789 e que, em Portugal e Espanha, foi igualmente usado, nos inícios do século XIX, como sinónimo

\footnotetext{
13 Universidade de Coimbra.
} 
de "regeneração". Não por acaso, esta foi a palavra a que os revolucionários liberais de Espanha (1810-1812) e de Portugal (1820-1822) recorreram para qualificar os movimentos políticos que lançaram a liquidação das estruturas sociais do Antigo Regime e os alicerces do sistema representativo. Ora, o elo umbilical entre revolução/regeneração manter-se-á no decurso de Oitocentos, embora a sua invocação tenha passado para as mãos dos que, considerando-o traído, queriam ir mais além na luta pela modernização da sociedade portuguesa. No entanto, não se pode esquecer que essa dinâmica desencadeou reacções contra-revolucionárias e, por conseguinte, críticas dos efeitos da modernidade, cuja crise somente seria resolvida por restauração ou por conservação. Daí que, a seu modo, as duas revoluções liberais ibéricas tenham convocado uma ideia de revolução que, se visava corrigir os excessos do seu paradigma francês, igualmente pretendia extinguir a crise das respectivas sociedades.

A ideia moderna de revolução terá ainda de ser chamada a terreiro para caracterizar outros períodos históricos, mesmo quando surgiu a enroupar a teleologia do materialismo histórico, condensada na irreversibilidade dos "modos de produção" e nas consequentes fases de transição. Mas, para o caso político português aqui especificamente em causa, bastará assinalar o ciclo que emergiu sob o signo da decadência e dos projectos avançados para a ultrapassar, a saber: o iniciado pela revolução vintista (1820-1822); o consolidado pela vitória liberal contra o absolutismo (desde os inícios da década de 1830 até 1910); o da revolução republicana (1910-1926); e o da chamada "revolução nacional", lançada por uma ditadura militar, de onde emergirá o Estado Novo salazarista (1926-1974).

Como facilmente se verifica, está-se na presença de experiências históricas cujas características comuns não podem encobrir o que as distinguia ou opunha. Seja como for, é indiscutível que, recorrendo a análogos diagnósticos decadentistas, todas se apresentaram com propósitos de levar a cabo a regeneração da decaída sociedade portuguesa, finalidade que, no entanto, implicou mudanças de regime, ou o recurso a soluções excepcionais, cada vez mais qualificadas como provisórias, ou como ditaduras morigeradoras. De onde a consabida ênfase que, desde 1820 até aos inícios da década de 1930, foi dada, no vocabulário político português, a termos 
como "decadência", "crise", "regeneração", "ressurgimento", "renascença", "novo", "revolução".

Seria um bom desafio indagar a maneira como todo este vocabulário foi usado para conotar as relações entre o passado e o futuro. Porém, como, com frequência, a terapêutica para esse diagnóstico transversal recorreu, não raro, a soluções ditatoriais - terminasse o seu cariz provisório no regresso pleno à normalidade anterior, ou na transição para um ordenamento constitucional novo -, será útil fazer uma viagem à tipologia das ditaduras, a fim de melhor se entender as características das que marcaram a vida portuguesa dos finais de Oitocentos e, sobremaneira, de várias décadas do século Xx. E, como as suas justificações se alicerçavam na necessidade de se responder, com carácter de necessidade e de urgência, a situações de crise, importa ter uma ideia das suas ocorrências, a fim de não se cair em diferenciações sem base (como, por exemplo, a que tende a representar o regime monárquico como uma realidade política estável, em contraste com a endémica instabilidade republicana). Só assim se poderá perceber a riqueza do debate sobre transições e ditaduras e melhor entender as características da primeira experiência histórica portuguesa que desejou fazer da ditadura um regime definitivo: o Estado Novo ${ }^{14}$.

\section{I}

\section{UMA INSTABILIDADE ESTRUTURAL}

Não será uma grande novidade defender que, em Portugal, devido à fraqueza da sociedade civil, a implantação do sistema representativo foi difícil. Não é este o lugar para se fazer a história das vicissitudes desse percurso $^{15}$, nomeadamente desde a Constituição de 1822 até à crise da

\footnotetext{
${ }^{14}$ Uma parte das páginas que se seguem também se encontra publicada em Fernando Catroga, "As Ditaduras entre a Monarquia Constitucional e a República", AA.VV., Justiça e Res Publica (séculos XIX-Xx), Braga, CITCEM, 2010.

${ }^{15}$ Para uma síntese deste itinerário, leia-se o que escrevemos em Fernando Catroga, "Em nome da nação", in F. Catroga e Pedro T. de Almeida, Respublica. Cidadania e representação política em Portugal. 1820-1926, Lisboa, Assembleia da República-Biblioteca Nacional de Portugal, 2010, pp. 21-59.
} 
República. Por ora, basta assinalar que tal debilidade foi ditada pelas características da base social que, com as suas especificidades próprias, deu vida aos regimes políticos pós-absolutistas dos países do Sul da Europa de dominância católica. Como se sabe, estes possuíam fracos índices de industrialização, urbanização e modernização ${ }^{16}$, e a sua população rural estava sujeita a uma longa tradição de dependências (nobiliárquicas, régias e eclesiásticas) passíveis de novas reactualizações.

\section{A instabilidade monárquico-constitucional}

Com efeito, os estudiosos do tema têm sublinhado a índole oligárquica do sistema, bem como a exiguidade da sua legitimidade eleitoral, pois sempre predominaram restrições (censitárias e capacitárias), comummente acompanhadas por práticas de manipulação das votações. E se, a partir da década de 1870, apareceram alguns sectores (republicanos) a reivindicarem o sufrágio universal (masculino) como único meio adequado ao respeito pelo conclamado princípio da soberania nacional, o certo é que esse alargamento nunca será reconhecido no período aqui em causa, não obstante, entretanto, ter entrado em vigor em países como a França (1848), a Suíça (1848), a Dinamarca (1849), a Grécia (1864) e a Espanha (1890). Em Portugal, sociedade de analfabetos (em 1910, a taxa rondava 70\% da população maior de 7 anos), as causas que condicionaram a continuidade desta capitis diminutio ultrapassam o problema das formas políticas, já que, apesar das promessas de democratização lançadas na fase da propaganda, depois do 5 de Outubro de 1910, os governos republicanos (exceptuando as eleições realizadas sob a ditadura de Sidónio Pais) nunca farão melhor do que no período monárquico.

Exemplifique-se, elegendo o ano de 1861 como ponto de partida e os seus $8,2 \%$ eleitores inscritos no total da população. A comparação mostra imediatamente que os valores máximos foram alcançados após a aprovação

\footnotetext{
${ }^{16}$ Cf. Salvador Fornel et al., Democracia, elecciones y modernización en Europa, Madrid, Ediciones Cátedra, 1995; Carlos Dardé Morales, "Cidadania e representação em Espanha. 1812-1923”, in F. Catroga e Pedro T. de Almeida, ob. cit., pp. 305-321.
} 
da lei eleitoral de 1878 (18,1\%) e em 1896 (18,8\%), números que, no final da Monarquia, irão cair para os 11,8\%. E se, em 1911, a República foi relativamente liberal na lei que promulgou para a eleição da sua Constituinte (14,2\%), logo em 1913, sob a influência de Afonso Costa, negou o direito de voto aos analfabetos chefes de família, levando os recenseados a patamares próximos dos mais baixos da época da Monarquia: 7,7\%, em 1915; $8,8 \%$, em $1925^{17}$.

Com isto, a experiência portuguesa aparecia como a manifestação máxima de um fenómeno que, contudo, também se manifestava em outras sociedades que, sob monarquias ou repúblicas, estavam a consolidar análogos sistemas representativos. Assim, se, em Portugal, entre 1895 e 1910, ocorreram 11 actos eleitorais, e 7 entre 1911-1926, importa recordar que, no mesmo período ${ }^{18}$, em Espanha, realizaram-se 8 e 6, respectivamente, na Grécia, 7 e 6, na Itália, 5 e 4. Mas os indicadores são igualmente altos em países como a Dinamarca (7 e 8) e a Suécia (5 e 7). Ao invés, a parlamentarista III República francesa revela boas taxas de estabilidade legislativa (só se realizaram 7 eleições gerais entre 1915 e 1926) ${ }^{19}$.

Ter-se-á de reconhecer que a fraca base eleitoral é um evidente sinal do elitismo oligárquico da vida política, défice aumentado pelas filtragens impostas pela diferenciação censitária entre eleitores e elegíveis (só a República modificará este desfasamento). A tudo isto devem somar-se, ainda, os altos valores da abstenção, em particular nos maiores centros populacionais, onde o poder de enquadramento dos caciques era mais difícil. De facto, tanto durante a Monarquia como na República, assistiu-se a uma mobilização clientelar do eleitorado, "com todo o cortejo de corrupção e tranquibérnias que lhe estavam associadas (a 'compra do voto', as célebres chapeladas, a viciação das actas)" ${ }^{20}$. De onde a abstenção em Lisboa e no Porto ter sido

\footnotetext{
${ }^{17}$ Sobre tudo isto, veja-se a esclarecedora síntese de Pedro T. de Almeida, "Eleitores, votos e representantes", in Fernando Catroga e Pedro T. de Almeida, ob. cit., pp. 61-89.

${ }^{18}$ Cf. António de Araújo, Instituições e poder político na I República (texto inédito, a que tivemos acesso devido à amabilidade do autor, a quem muito agradecemos).

${ }^{19}$ Cf. Pedro T. de Almeida, ob. cit., p. 64.

${ }^{20}$ Idem, ibidem, p. 79.
} 
sempre muito elevada: de 1878 a 1910, a taxa média de efectivos votantes, entre os recenseados, foi da ordem dos 48\% e dos 55\%, respectivamente ${ }^{21}$.

A mediação do jogo político, feita por "partidos" com um mínimo de estrutura orgânica e programática, ganhou uma maior visibilidade depois dos inícios da década de 1870. No entanto, é igualmente verdade que eles continuarão a estribar-se em lideranças personalizadas, "notáveis" que, da capital, controlavam uma rede de caciques ("caciquismo de proprietários" e "caciquismo de burocratas") que descia ao distrito, deste ao município, e daqui à paróquia ${ }^{22}$. E o Partido Republicano, principalmente após 1906, foi o único que conseguiu alcançar uma organicidade mais moderna e activa (que João Franco procurará imitar), bem coadjuvada por uma imprensa agressiva (contava com alguns diários de grande circulação e com dezenas de jornais de âmbito local e regional). De qualquer modo, nunca deixou de ser uma federação de personalidades e de tendências, e a sua fragmentação, logo após o 5 de Outubro de 1910, fará prolongar muitas das características que definiram o perfil das formações políticas das décadas anteriores $^{23}$. Em suma: ao elitismo juntava-se a sua natureza predominantemente oligárquica, fonte de pugnas endógenas que, nos seus momentos de maior crise, ganharão mesmo contornos de autofagia.

Excluindo os republicanos com as suas várias tendências, nas últimas duas décadas do século XIX e inícios do século Xx, à intensidade da disputa política correspondeu um fraco nível de oferta de programas que, voltados para o convencimento dos eleitores, oferecessem verdadeiras alternativas entre si. O seu alvo político estava sobretudo fixado na captação da influência dos notáveis e das suas redes clientelares. Por isso, tratou-se, sobremaneira, de uma competição no interior de elites politizadas em luta à volta desta certeza: para se reproduzirem, tinham de controlar, o mais tempo possível, o poder do Estado que estavam a construir, o que acen-

\footnotetext{
${ }^{21}$ Idem, ibidem.

${ }^{22}$ Cf. Fernando Catroga, "O poder político-administrativo das paróquias em Portugal", Revista de História da Sociedade e da Cultura, n. 4 , 2004, pp. 149-255.

${ }^{23}$ Cf. Fernando Farelo Lopes, Poder político e caciquismo na 1. ${ }^{a}$ República, Lisboa, Editorial Estampa, 1994, e "Partidos e representação no período liberal em Portugal", in F. Catroga e Pedro T. de Almeida, ob. cit., pp. 258-289.
} 
tuou as crises, fossem estas de origem financeira (como as que eclodiram nos inícios da década de 1870 e de 1890), de cariz patriótico-colonial (Ultimatum de 1890), de cunho tributário (recorde-se, a este propósito, a evolução política dos lojistas de Lisboa), ou tivessem a sua fonte em escândalos ligados à corrupção (concessão dos Tabacos, por exemplo), ou aos adiantamentos financeiros à Casa Real, sem aval e conhecimento do Parlamento.

Da conjugação de todos estes factores resultou uma quase permanente instabilidade governativa e parlamentar, realidade que, ao contrário do que se pensa, não constituiu um exclusivo da I República. Na verdade, e de acordo com a síntese feita por António de Araújo, na Monarquia Constitucional, entre 1834 e 1910, apenas 6 legislaturas se completaram com 4 sessões. Recorde-se: no reinado de D. Maria II, existiram 20 governos em 19 anos (ou seja, uma média de um por ano); no de D. Pedro V, 4 em 8 anos; no de D. Luís, 14 em 28 anos: mas, entre 1868 e 1871, houve 5 eleições, 1 golpe de Estado (a última "saldanhada") e 8 governos. Por sua vez, D. Carlos teve 14 governos em 19 anos, e D. Manuel II, 6 em 2 anos. Em suma: em 76 anos do Portugal monárquico-constitucional, tomaram posse 78 governos e realizaram-se 43 eleições.

Este panorama pode surpreender, principalmente aqueles que acusam o parlamentarismo de ser o principal responsável pela instabilidade política, diagnóstico que se esquece, porém, de que, segundo a Carta Constitucional, cabia ao Chefe do Estado não só nomear o governo, como dissolver as Cortes, capacidade que foi frequentemente usada para desbloquear crises e garantir alternâncias. Por outro lado, também se sabe que a introdução do poder moderador e de uma segunda Câmara de nomeação régia visou salvaguardar o funcionamento de um sistema "misto" e "equilibrado", ideal que, na perspectiva dos conservadores, o unicameralismo e o parlamentarismo da Constituição de 1822 seriam incapazes de cumprir.

Ora, se, na sua fase de maturidade, o modelo ainda foi dando uma relativa resposta aos novos conflitos, o mesmo não se poderá afirmar quando estes cresceram sob o efeito das transformações decorrentes do paulatino processo de liquidação das heranças do Antigo Regime. E, se o ordenamento constitucional foi pensado para que o poder moderador pu- 
desse garantir a autonomia dos outros três poderes, o seu funcionamento revela que boa parte da legislação que estruturou o regime foi promulgada em ditadura. Daí que, para os republicanos e para alguns monárquicos, esta prática sinalizasse uma excessiva intromissão régia que adulterava a representação da soberania nacional, já que todos os governos que realizaram as eleições nunca as perderam. Assim, não surpreende que o distanciamento desta banalização aparecesse consorciado, em alguns casos, com as anatematizações lançadas contra o parlamentarismo e em nome de alternativas autoritárias. E, como é lógico, tais críticas não tinham uma origem exclusivamente portuguesa.

Em França, na sequência do "complexo" criado pelo desfecho da guerra franco-prussiana (1870), há muito que um sector importante das elites políticas e intelectuais olhava, com atenção redobrada, para a Alemanha e para o seu modelo "bismarckiano" de Estado, nem que fosse para melhor o combater. Este intento ganhou força nas correntes que contestavam a interpretação que estava a ser feita das Leis Constitucionais (1875). De facto, embora estas dessem ao Presidente da República o poder de dissolução, o uso que, em 1877, Mac-Mahon fez dessa faculdade levou-o à derrota eleitoral e à introdução de um entendimento mais parlamentarista do ordenamento jurídico da III República.

Em 1886-1891, uma outra alternativa surgiu com objectivos análogos: o "boulangismo". Este movimento, liderado por uma figura militar (o general Georges Boulanger), propugnava por uma reforma constitucional de orientação plebiscitária, nacionalista e autoritária. E este clima ficou ainda mais tenso com as incidências ideológicas do caso Dreyfus, bem como com o crescente impacto de uma doutrinação tradicionalista e de um revolucionarismo contra-revolucionário (Barrès, Charles Maurras, Jean Valois, entre outros) ${ }^{24}$, cujos principais adversários eram não só os ascendentes movimentos socialistas como os sistemas políticos centrados no indivíduo-cidadão, fossem eles monárquicos ou republicanos, democráticos ou simplesmente liberais.

\footnotetext{
${ }^{24}$ Cf. Zeev Sternhell, La Droite révolutionnaire. 1885-1914. Les origines françaises du fascisme, Paris, Seuil, 1978.
} 


\section{A apologia do engrandecimento do poder real}

Em Portugal, algumas das críticas ao sistema representativo previsto na Carta não foram alheias à experiência de Bismarck ${ }^{25}$ e ao pensamento político alemão, cujas virtudes começaram a ser exaltadas como arma de arremesso contra o parlamentarismo demoliberal e os socialismos revolucionários. Frise-se que, logo nos inícios da década de 1870, Oliveira Martins - à luz da influência do socialismo catedrático alemão, mesclada com ecos do krausismo (Ahrens) e com uma leitura organicista (Spencer) de Proudhon começou a teorizar a reforma do ordenamento político português, propondo uma representação de origem corporativa (As Eleições, 1878) ${ }^{26} \mathrm{e}$ o fortalecimento do poder executivo. Na década seguinte, o projecto materializar-se-á na Vida $\mathrm{Nova}^{27}$, corrente que medrou no seio do Partido Progressista e que contará com o apoio de alguns dos seus melhores amigos: Antero de Quental, Carlos Lobo D’Ávila, Eça de Queirós, Ramalho Ortigão, Luís de Magalhães. E o jovem D. Carlos (que subiu ao trono nos finais de 1889) não the foi indiferente.

O núcleo essencial da proposta tinha a ver com a reforma corporativa da representação e com a defesa do "trabalho nacional", medidas que exigiam o reforço do poder executivo, ou melhor, uma "política de engrandecimento do poder real", a implantar num período de transição, no qual o Monarca devia explorar, ao máximo, as competências que estariam potenciadas no poder moderador que detinha, nem que tivesse de cair numa espécie de novo cesarismo. Não por acaso, Oliveira Martins lembrava que este irrompia em épocas de forte crise social como "um tipo novo de soberania que saía espontaneamente da anarquia da república" e que significava "a abdi-

\footnotetext{
25 Retomamos e desenvolvemos algumas ideias expostas em Fernando Catroga, "O problema político em Antero de Quental. Um confronto com Oliveira Martins", Revista de História das Ideias, n. ${ }^{3}$ 3, 1981, p. 88 ss; António Manuel Hespanha, "A representação orgânica", in Fernando Catroga e Pedro T. de Almeida, ob. cit., p. 124 ss.

${ }^{26}$ Cf. Oliveira Martins, As Eleições (1878), Lisboa, Em Casa da Viúva Bertrand, 1878.

${ }^{27}$ Cf. F. A. De Oliveira Martins, O Socialismo na Monarquia. Oliveira Martins e a "Vida Nova", Lisboa, Parceria F.A. de António Maria Pereira, 1944.
} 
cação do poder democrático instituída em regra e tornada permanente sem todavia ser declarada" 28 .

O projecto pretendia pôr em causa tanto as insuficiências do parlamentarismo como a incapacidade regeneradora da ditadura republicana à romana. É que esta implicava, como se verá, uma transitoriedade que somente suspendia a ordem constitucional existente para se regressar, logo que a crise estivesse resolvida, ao status quo ante. Deste modo, se a leitura martiniana do cesarismo também assumia o cariz provisório da experiência, o seu desfecho seria, porém, diferente, pois que, em última análise, almejava criar uma realidade constitucional nova. Por palavras suas: se o cesarismo constituía "por sua natureza um episódio transitório na vida agitada das sociedades minadas pelas revoluções" ${ }^{29}$, ele só teria efeitos positivos se fosse "caminho para a constituição da representação orgânica"30, ultrapassando, assim, a pretensa auto-suficiência do indivíduo e o posicionamento pouco activo do poder régio.

Antero de Quental concordava com o amigo. Entre outros testemunhos, confirma-o a carta que, em Agosto de 1885, enviou a Cirilo de Carvalho a explicar a estratégia: uma vez no poder, "depois de reformar a constituição económica”, ir-se-ia "organizar a constituição política, tanto no que toca ao legislativo, como ao executivo, de modo a dar estabilidade e duração aos progressos realizados"31. No mesmo registo se encontra a posição de Eça de Queirós. Numa missiva de 7 de Outubro de 1890, dirigida a Martins, escreveu: "enquanto à Cousa Pública, que te direi? Nada compreendo do que se está passando(...). Em todo o caso, não vejo senão uma solução simplista - uma Tirania. É necessário um sabre, tendo ao seu lado um pensamento. Tu és capaz de ser o homem que pensa - mas onde está o homem que acutila?" E, revelando que o assunto já tinha sido tratado entre ambos, rematava: "Em antigas cavaqueiras falámos por vezes do Rei. Mas é ele um

\footnotetext{
${ }^{28}$ Oliveira Martins, História da República Romana, vol. 2, 3. ${ }^{a}$ ed., Lisboa, Parceria António Maria Pereira, 1919, p. 363.

${ }^{29}$ Idem, ibidem, vol. 1, p. 27.

${ }^{30}$ Idem, Política e Economia Nacional, Lisboa, Guimarães Editora, 1954, p. 72.

31 Antero de Quental, Cartas, Coimbra, Imprensa da Universidade, 1921, p. 270.
} 
Homem? Ou é ele simplesmente um Ceptro?" Por sua vez, depois da fugaz e fracassada passagem do impulsionador da Vida Nova pelo Ministério da Finanças, Alberto de Sampaio profetizava (1.1.1893): "um governo violento, com o rei ou com a república, cada vez se me afigura mais fatal" 32 .

Todos estes juízos de valor denotam uma assumida depreciação do sistema parlamentar, acompanhada pela defesa, pelo menos ao nível de uma segunda Câmara, da representação orgânica já propugnada, nos anos de 1860, pelos krausistas ligadas à Faculdade de Direito da Universidade de Coimbra ${ }^{33}$ e, desde os inícios da década seguinte, por Oliveira Martins (e Antero). Foi o caso de António Cândido: em 1882, explicava que, quanto à reforma constitucional, votava "convictamente qualquer proposta que aplique à segunda Câmara o princípio da representação orgânica. É um ensaio a fazer, e, com certeza, um grande progresso sobre o que está; por outro lado, é inquestionável que nas sociedades modernas a aristocracia é constituída pela capacidade intelectual, pelas magistraturas sociais e pela riqueza; e eu, cada vez menos radical, prefiro mil vezes que a lei fixe os representantes dessa aristocracia a que os escolha e exalte o que aí se chama a vontade popular"34. Mais tarde, por diapasão análogo afinará Carlos Lobo D’Ávila, figura próxima de Oliveira Martins e também membro dos chamados Vencidos da Vida, nomeadamente quando, em finais de Outubro de 1889, escreveu a D. Carlos com o fito de o convencer de que o sistema representativo vigente estava caduco: "o parlamentarismo, Senhor, teve o seu tempo (...). Reconhecido que o sufrágio, como significação da vontade nacional, é uma utopia generosa e irrealizável, Vossa Majestade não pode sujeitar o seu Governo ao capricho das votações parlamentares"35.

A crítica à Carta Constitucional era uma das faces da rejeição do sistema parlamentar e dos alicerces da sua legitimação: o sufrágio atomizado. E, se

\footnotetext{
32 Alberto Sampaio, Correspondência inédita, Guimarães, Tip. Minerva, 1941, p. 38.

33 Cf. Cabral de Moncada, Subsídios para a bistória da filosofia do direito em Portugal (1772-1911), 2. ${ }^{a}$ ed., Coimbra, Coimbra Editora, 1938, p. 39 ss.

${ }^{34}$ António Cândido, "Carta de... a Oliveira Martins", in F.A. de Oliveira Martins, D. Carlos I e os "vencidos da vida", 2. a ed., Lisboa, Parceria António Maria Pereira, 1941, p. 150.

35 Carlos Lobo D’Ávila, "Carta a Sua Majestade El-Rei”, in Gomes Monteiro, Vencidos da vida, Lisboa, Romano Torres, 1944, p. 182.
} 
Carlos Lobo D’Ávila foi explícito na sua condenação, outros ainda o aceitavam mas com o objectivo de, a prazo, o tornarem desnecessário. Dir-se-ia que em tudo isto perpassava uma auto-afirmação de méritos adquiridos no actualizado conhecimento dos ensinamentos das ciências sociais, convencimento que teve a sua expressão ditatorial máxima em A. Comte, ainda que de um modo ecléctico, este pano de fundo não deixasse de estar presente que, no espírito de muitos dos adeptos da Vida Nova. Aliás, Ramalho Ortigão, antigo positivista e biógrafo de Teófilo Braga, insinuou esse parentesco, ao declarar, ao jornal O Tempo (Outubro de 1889), que o sufrágio só valia "enquanto o cérebro da sociedade não adquirir consistência necessária para compreender que a função do governo é puramente científica e tem de se basear em uma correlativa organização técnica"36.

Demais, a proclamação desta superioridade aparecia geminada com o enaltecimento das virtudes do modelo orgânico, casamento bem plasmado na obra de Jaime de Magalhães Lima, intitulada A Democracia. Estudo sobre o governo representativo (1888) e escrita para provar que a legitimação do poder não deveria radicar no sufrágio universal. Ao contrário, teria de reactualizar os laços sociais dissolvidos, que "os erros políticos destruíram em vez de transformar" 37 , a partir das novas condições resultantes do desenvolvimento industrial.

Com estes argumentos, os apóstolos do engrandecimento do poder real queriam convencer o Monarca a governar, e não só a reinar, nem que para isso tivesse de recorrer à usual ditadura ordinária, desiderato que não andou longe da estratégia que norteou boa parte das excepções ditatoriais que advieram depois de 1890. E ao velho Ramalho Ortigão não escapou essa filiação, mormente quando, lastimando o assassinato de D. Carlos e do príncipe Luís Filipe, em 1 de Fevereiro de 1908, a sintetizou deste modo: "a teoria do 'engrandecimento do poder real', enunciada por alguns intelectuais do grupo a que pertencia Oliveira Martins, o que era, no íntimo da sua palpável inconstitucionalidade, senão um desenvolvimento da con-

\footnotetext{
${ }^{36}$ In F.A. de Oliveira Martins, ob. cit., p. 157.

${ }^{37}$ Jaime de Magalhães Lima, A Democracia. Estudo sobre o governo representativo, Porto, Typ. de A. J. Teixeira, 1888, pp. 66-68.
} 
vicção de todos os espíritos independentes, acerca da estéril e perigosa passividade do poder moderador? O erro da neutralidade monárquica perante o escândalo da administração pública corrigia-se coerentemente com a rectificação atrevida de uma fórmula consagrada: 'o rei reina e tem obrigação de governar"'38.

Quer isto dizer que não se travava de uma proposta em que, sanada a crise, se regressaria à situação anterior. Desejava-se mexer nos próprios fundamentos da legitimação política, ampliar a representação dos corpos sociais e enfatizar o ascendente do poder executivo sobre o legislativo, prova de que, mesmo antes da massificação da política, a conflitualidade no interior das elites politizadas deu curso a propostas em que o acasalamento do autoritarismo com o corporativismo - a partir da mitificação dos medievos corpos intermédios, ou dos novos "agregados sociais" que estavam a nascer com a sociedade industrial - caminhou a par do combate contra os princípios que norteavam os sistemas demoliberais modernos. E esta peleja foi acompanhada pela auto-reivindicação, pelos críticos, de uma competência e de um posicionamento ético superior ao das facções que se alternavam no poder.

Equacionando todos estes modos de pensar, não basta dizer que o termo "ditadura" se popularizou nos princípios do século xx, pois, se não se chamar a terreiro os fundamentos da afirmação, poder-se-á sugerir que se esteve perante algo que data deste período, ou que somente decorreu sob o impacto da chegada das massas à vida política. Ora, não se pode obvidar que também há lugar a que se pergunte se esta crise, mais do que uma consequência da erosão da normalidade, não foi a sua faceta constituinte fundamental, numa prolongada manifestação das dificuldades de enraizamento, em Portugal (e em outros países do Sul da Europa), dos sistemas representativos inspirados na "liberdade dos modernos".

Atente-se nestes dados: de acordo com os cálculos feitos pelo Barão de S. Clemente, só entre 1852 e 1889 terão funcionado doze governos em di-

\footnotetext{
38 Ramalho Ortigão, "Rei D. Carlos, o martirizado", Últimas Farpas, Lisboa, Clássica Editora, 1964, p. 227.
} 
tadura ${ }^{39}$, prova de que, afinal, a excepção também funcionou como regra. Como, em 1909, escrevia Alberto dos Reis, professor da Faculdade de Direito da Universidade de Coimbra, o poder ditatorial foi "largamente usado pelos governos: desde os inícios do regime liberal até à actualidade, os ministérios têm com a maior facilidade e desprendimento lançado mão deste processo que pela sua própria índole devia ser considerado como recurso extremo" ${ }^{40}$. Chegou-se mesmo ao ponto de, em ditadura, se ter legislado sobre matéria constitucional, como ocorreu com os Actos Adicionais à Carta Constitucional de 5 de Junho de 1852, de 25 de Setembro de 1895 e de 23 de Dezembro de $1907^{41}$, bem como com a aprovação de boa parte da codificação liberal.

\section{A instabilidade republicana}

Como é sabido, para os republicanos não havia dúvidas: a existência de uma ordem constitucional que dava ao Rei, ungido pela graça de Deus e somente legitimado pelo princípio hereditário, o poder de intervir na vida política tinha transformado o Chefe de Estado no principal responsável pela disfunção do sistema. Pode sustentar-se, até, que, a par do impacto do sucesso da experiência do parlamentarismo republicano francês, o fantasma do engrandecimento do poder real e a reacção contra as sucessivas ditaduras convenceram a maioria dos constituintes de 1911 a instituir uma República parlamentar e, com o receio de degenerescências cesaristas e autoritárias, a não reconhecer a eleição directa do Presidente e, portanto, a não lhe conferir o direito de veto suspensivo e de dissolução. Contra as

${ }^{39}$ In Luís Bigotte Chorão, A Crise da República e a Ditadura Militar, Lisboa, Sestante, 2009, p. 330, nota 1078 .

${ }^{40}$ Alberto dos Reis, Organização judicial. Lições feitas ao curso do $4^{\circ}$ anno juridico de 1908 a 1909, Coimbra, Imprensa Academica, 1909, pp. 40-41; Marnoco e Sousa, Direito Político, poderes de Estado, sua organização segundo a sciencia politica e o direito constitucional português, Coimbra, França Amado, Editor, 1910, p. 757.

${ }^{41}$ Manuel Pinto dos Santos, Monarquia Constitucional. Organização e relações de poder governamental com a Câmara dos Deputados, Lisboa, Assembleia da República, 1986, pp. 198-199. 
ditaduras, julgou-se, então, que esse seria o caminho mais seguro para se salvaguardar a estabilidade política.

As coisas não ocorrerão assim, pois o mal que se queria curar agudizar-se-á, prova de que o fenómeno não tinha causas meramente conjunturais, ou ligadas à questão do regime. As suas raízes seriam mais fundas, já que, mesmo a existência de maiorias partidárias no Parlamento não bastou para instalar a normalidade governativa. De facto, das 8 eleições legislativas que ocorreram entre 1910 e 1926, o Partido Democrático (explorando bem o regime de escrutínio e de círculos que ele próprio ajudou a implementar) só não venceu a de 1921 (ganha pelo Partido Republicano Liberal); e, quanto às restantes, só não obteve maioria na de $1922^{42}$. No entanto, os executivos republicanos somente duraram, em média, 93 dias, esperança de vida que foi mínima entre Janeiro de 1920 e Março de 1921, fase em que António José de Almeida chamou ao Palácio de Belém 10 governos. Por sua vez, as eleições realizaram-se de dois em dois anos, e a duração média das legislaturas foi de 1,8 anos. Em síntese: entre 1910 e 1926, formaram-se 45 executivos, $45 \%$ dos quais de coligação. Destarte, não será excessivo apresentar como uma das causas desta aparente contradição a debilidade da disciplina partidária, apesar do caudilhismo que polarizava os agrupamentos políticos.

Por sua vez, a eleição indirecta do Presidente da República (pelo Parlamento e pelo Senado, reunidos em Congresso) e a não-dissolução, ao bloquearem a capacidade para se corrigirem os excessos da predominância do poder legislativo sobre os demais, não foi causa menor para que a excepção continuasse a ser a regra. É que, com isso, aquele detinha a faculdade de demitir, ou levar à demissão, o Presidente. Fosse na sequência de agitações parlamentares, de rua ou de ambas conjugadas, a instabilidade também atravessou a Presidência. Com efeito, dos oito Chefes de Estado que exerceram funções na vigência da Constituição de 1911 (média de 1 de dois em dois anos), só António José de Almeida (1919-1923) exerceu plenamente o seu mandato, e houve um ano - 1915 - em que Portugal teve três ${ }^{43}$.

\footnotetext{
${ }^{42}$ Cf. António de Araújo, art. cit., p. 20.

${ }^{43}$ Idem, ibidem, p. 14.
} 
Além do mais, rapidamente cresceu a ideia de que a legislação eleitoral, aprovada em 1913, não só enfraquecia a legitimidade dos governos como estava a cimentar um novo caciquismo, colocando fora do sistema muitas opções ideológicas. Em simultâneo, a hegemonia de um só partido (o Democrático) foi combatida por várias frentes conspirativas, num crescendo de militarização que desembocará no 28 de Maio de 1926.

Por tudo isto, compreende-se que os problemas do sufrágio e do direito presidencial à dissolução tenham sido tão enfatizados no decurso da I República. Para muitos, sem o reconhecimento dessa faculdade, bem como sem uma nova lei eleitoral, a ditadura da maioria parlamentar (entenda-se: a do Partido Democrático) prolongar-se-ia.

Em 1919, finalmente, uma reforma constitucional introduziu a dissolução, embora condicionada pelo parecer de uma comissão coordenadora nomeada pelas tendências políticas com assento parlamentar. Ora, apesar da sua imediata aplicação (por António José de Almeida), rapidamente se percebeu que a instabilidade não diminuía. Bem pelo contrário: a fragmentação partidária (ou para-partidária) aumentou, ao mesmo tempo que a legitimação indirecta dos poderes do Presidente enfraquecia as suas decisões, o que fez crescer as pressões sobre ele por parte dos grupos em litígio e, em particular, dos militares (de média e alta patente) cada vez mais descontentes, social e profissionalmente, com a sua situação no após-guerra.

Em termos de média duração, o caso português indica que, com dissolução (a Monarquia Constitucional), ou sem ela (a República, de 1911 a 1919), a separação de poderes teve sempre muita dificuldade em se fazer respeitar. Daí a distância que existiu entre a letra das Constituições e a acção política, e esta outra irrecusável constatação: na prática, impôs-se uma clara hegemonia do poder executivo sobre o legislativo. Sintoma do papel fundamental que as ditaduras tiveram na modelação do sistema, tanto sob a sua forma monárquica como republicana, e indício indiscutível desta outra verificação: o poder, conquanto se assumisse como representante, sabia que teria de ser ele a produzir a realidade que afirmava representar.

Escrevendo em 1910, um respeitado jurista (Marnoco e Sousa) não tinha dúvidas: "a ditadura não pode existir sem que o poder executivo 
estabeleça normas de carácter legislativo, mas, para além disso, é necessário que estas normas sejam decretadas pelo poder executivo, usurpando este as funções do poder legislativo". No entanto, o que aqui se tratava não dizia respeito à chamada ditadura soberana, mas às que, previstas ou não pela realidade constituída, somente visavam solucionar situações excepcionais de crise, não pondo em causa a ordem constitucional estabelecida. Por isso, o grande debate sobre a ilegalidade ou não das decisões legislativas tomadas em ditadura, que se agudizará com o último governo de João Franco (1907-1908), terá sobretudo por objecto as providências legislativas que "o poder executivo publica por exclusiva iniciativa sua" ${ }^{4}$, e não tanto as atinentes à declaração de estado de sítio feita de acordo com o que constitucionalmente estava previsto ${ }^{45}$. Como é evidente, o constitucionalista de Coimbra tinha em mente o longo rol de ditaduras ordinárias em que, nos intervalos das sessões legislativas, ou nos períodos de dissolução do Parlamento por iniciativa régia, o executivo legislou através de decretos com força de lei e que, portanto, entravam imediatamente em vigor.

\section{II}

\section{UMA TIPOLOGIA DAS DITADURAS}

A par das experiências gregas (Sólon), havia o conhecimento histórico do antiquíssimo recurso romano à ditadura, existia a memória das ditaduras revolucionárias recentes (como a instaurada pela Convenção) e havia notícia de versões - como a ditadura positivista, ou a ditadura de classe - que vieram enriquecer o campo das ofertas autoritárias, numa correspondência directa com o aumento da conflitualidade social e política, sobremaneira a partir de meados da primeira década do século xx.

\footnotetext{
${ }^{44}$ Marnoco e Sousa, ob. cit., p. 746.

${ }^{45}$ Idem, ibidem.
} 


\section{A ditadura republicana}

Em termos tipológicos, as ditaduras conhecidas podem ser resumidas a dois grandes modelos: a "ditadura comissarial" e a "ditadura soberana" (Carl Schmitt). A primeira teve a sua manifestação pioneira na ditadura republicana à romana, enquanto a segunda entronca em Rousseau e na Revolução Francesa. E, se o substantivo revela a existência de similitudes, a adjectivação do sintagma aponta para diferenças que têm de ser sublinhadas.

Quanto às características comuns, duas são indiscutivelmente compartilhadas. Referimo-nos ao cariz excepcional de ambas - a que tanto podia seguir-se o regresso à ordem anterior, como a construção de um novo ordenamento político -, bem como à presença deste objectivo análogo: responder a situações de necessidade e de urgência, ou melhor, de crise, a fim de as regenerar. Assinale-se, agora, o que mais de essencial as distingue.

A ditadura à romana, frequente durante a República, não era de índole pessoal e devia-se à iniciativa do poder estabelecido: o Cônsul, geralmente a pedido do Senado, que delegava num ditador competências para agir nas condições assinaladas, prática que a máxima de Cícero: consul videat ne quid res publica detrimenti capiat (o Cônsul providenciará para que a República não seja prejudicada) bem exprimia. Por isso, a excepcionalidade não só era transitória, como reversível, perdendo a sua razão de ser quando se restabelecesse a ordem anterior que a tinha constituído. Seria uma espécie de "ditadura comissarial" (Carl Schmitt) ${ }^{46}$, suspensão da normalidade que não devia exceder os seis meses, ou o período que durava o mandato de quem mandatou o ditador. E a sua personalização (não se tratava de uma ditadura de assembleia, gabinete ou grupo) distinguia-se da do cesarismo, porque, ao contrário deste, não se formava por usurpação e concentração de poderes e por um tempo não demarcado. Era, em suma,

\footnotetext{
${ }^{46}$ Sobre este conceito e o de "ditadura soberana", veja-se a obra, publicada em 1921, de Carl Schmitt, La Dictadura. Desde los comienzos del pensamiento moderno de la soberanía hasta la lucha de clases proletaria, Madrid, Revista de Occidente, 1968, bem como o que escreveu (1922) em Teología política. Cuatro ensayos sobre la soberanía, Buenos Aires, Editorial Struhart, 1998; e Giorgio Agamben, Stato di eccezione, Torino, Bollati Boringhieri, 2003.
} 
uma ditadura republicana instituída para salvar a República, e não uma ditadura perpétua instaurada para a destruir.

\section{A ditadura soberana ou convencionalista}

A partir da Revolução Francesa, brotou um outro tipo de ditadura, em cuja génese é possível detectar o cruzamento de dois novos pressupostos: as modernas concepções contratualistas de soberania e uma representação irreversível e qualitativa do tempo histórico. Com esta, também cresceu o desfasamento entre o ser e o dever ser, o que potenciou o entendimento da diacronia social como um processo mergulhado numa crise permanente, condicionantes que têm de ser convocadas, a fim de melhor se apreender quer os vários sentidos de ditadura no contexto da era das revoluções modernas (rupturas mediadas pela acção humana), quer as respostas contra-revolucionárias que elas desencadearam. Como se viu, Carl Schmitt chamou-lhes "ditaduras soberanas", mas Hariou definiu-as como "ditaduras convencionalistas".

Mais em pormenor, convém dizer que, na ditadura soberana, o ditador, directa ou indirectamente escudado na força, apela a uma instância fundadora do seu poder de quem se declara comissário directo (um dos seus exemplos pioneiros encontra-se na Convenção). Ao contrário do caso romano, a excepção irrompe contra a norma e, em nome do povo, da nação, da classe, da raça, da razão iluminada, afirma-se, não como um mero despotismo, mas como o poder constituinte de uma realidade nova, ao mesmo tempo que recalca a previsão do seu fim, fazendo-o depender, exclusivamente, da sua vontade incondicionada. Em conclusão: "o ditador comissário é o comissário de acção incondicional de um pouvoir constitué; a ditadura soberana, a comissão de acção incondicional de um pouvoir constituant" ${ }^{47}$; ou ainda: "o ditador comissário é constituído; o soberano, constituinte"48.

\footnotetext{
${ }^{47}$ In Alexandre Franco de Sá, O Poderpelo poder. Ficção e ordem no combate de Carl Schmitt em torno do poder, Lisboa, Centro de Filosofia da Universidade de Lisboa, 2009, p. 114.

${ }^{48}$ José Manuel Correia Pinto, "Notas sobre o conceito de ditadura. Parte III" (http://politeiablospotcom.blogspot.com/2008/11/notas-sobre-o-conceito-de-ditadura_4711.html; 19 Maio 2009).
} 


\section{A ditadura do proletariado}

Estas tipificações têm sobretudo um valor instrumental, já que as características descritas aparecem misturadas, consentindo vários subtítulos. Por exemplo, dentro da fenomenologia da ditadura soberana, desde logo deve ser destacada a "ditadura do proletariado", não só porque Marx iniciou a sua formulação por volta de 1848, mas também porque, com Lenine e com a revolução soviética de 1917, a sua aplicação ganhou ressonância mundial. E, se é indiscutível que ela tem pouco de comum com a ditadura republicana à romana, também se distancia, em muitos pontos, da pureza do tipo em que deve ser inserida. Compreende-se. A sua fundamentação inspirava-se numa teoria sociológica do poder e numa das versões mais fortes da visão moderna do tempo histórico, horizonte que explica por que é que ela pôs em causa a ideia de excepcionalidade inerente às demais concepções. Com efeito, para o marxismo, todas as ditaduras (até à ditadura do proletariado) seriam permanentes, porque intrínsecas ao exercício do poder de dominação nas sociedades atravessadas por antagonismos de classe.

A recepção portuguesa desta ideia, com uma maior ou menor riqueza teórica, será feita a partir de finais da década de 1870 pela chamada corrente marxista do socialismo português. De qualquer modo, a sua tradução leninista organizada ocorrerá nos inícios da década de 1920 (formação do Partido Comunista Português, em 1921) e irá ter uma longa vida até ao período da revolução democrática de 1974 (ou mesmo um pouco depois), embora a sua corrente mais forte, isto é, o PCP, tendesse, cada vez mais, a recalcá-la. Porém, nas décadas imediatamente anteriores, o seu principal ideólogo - Álvaro Cunhal - ainda sentia a necessidade de ao 25 de Abril, clarificar a natureza sui generis dessa ditadura, ensinando que ela "não significa uma forma particular de dominação de uma ou várias classes, mas o próprio facto dessa dominação" ${ }^{29}$, pelo que a sua função última seria apropriar-se do Estado, tendo em vista usá-lo para acabar com o carácter

\footnotetext{
49 Álvaro Cunhal, A Questão do Estado. Questão central de cada revolução, Lisboa, Editorial "Avante!", 1977, p. 3.
} 
ditatorial de toda a dominação, ou, por outras palavras, para "substituir a ditadura de minorias pela ditadura da imensa maioria ${ }^{50 "}$. No entanto, a sua instauração, por via revolucionária, comungaria da vocação constituinte da ditadura soberana, pois seria, igualmente, uma fase de transição para uma realidade nova, que extinguiria a índole ditatorial do poder político.

A ditadura do proletariado também estava nos antípodas do cesarismo (aliás, Marx criticou o termidor e a usurpação imperial que o sobrinho de Napoleão levou a efeito em 1851). Quando muito, consente alguma analogia com a "ditadura convencionalista", devido, sobretudo, ao seu exercício colectivo, embora não convocasse qualquer conceito "metafísico" de soberania para se justificar. O materialismo histórico caracterizava-a como a ditadura da classe que, com a proletarização capitalista, nada teria para defender (de seu, somente detinha a força de trabalho) e que, por isso, possuiria capacidade para fazer coincidir as suas reivindicações com as da luta pela libertação de toda a humanidade.

\section{A ditadura positivista}

Na segunda metade do século xix, a influência do pensamento de Augusto Comte e de algumas leituras ortodoxas das suas obras mais tardias pôs em voga a defesa de uma nova modalidade de ditadura, alicerçada na absoluta primazia que, tanto ao nível do poder espiritual como do temporal, devia ser dada aos que detivessem um conhecimento científico das leis da sociedade. O paradigma era a Convenção, mas a sua legitimidade resultaria da conquista da opinião pública por parte dos que, munidos da força de convencimento que decorreria da presumida objectividade dos seus argumentos (tidos por científicos), iriam concitar o reconhecimento. As suas decisões, escoradas numa pretensa cientificação da política, criariam um consenso análogo ao que gozavam as leis científicas, tendo, por isso, capacidade para extinguir os conflitos típicos das sociedades organizadas de acordo com princípios teológicos e metafísicos. Em suma: tratar-se-ia de

\footnotetext{
${ }^{50}$ Idem, ibidem, pp. 17, 61-62.
} 
uma espécie de "ditadura dos saberes", ou, na linguagem de Comte, de uma sociocracia ${ }^{51}$.

Sublinhe-se que ele escreveu numa conjuntura em que a nova questão social $^{52}$, nascida das contradições da sociedade científico-industrial (na linguagem dos saint-simonianos, que também era a sua), tinha emergido e ganhado actualidade, e que buscou conciliar a ordem com o progresso. Fêlo em nome de um plano que explorava o prestígio da ciência - a sua sociologia seria mais científica do que a economia política ${ }^{53}$-, mas para o colocar ao serviço de uma política conservadora ${ }^{54}$. Se, em função da lei dos três estados (postulada como sendo científica), o absolutismo seria anacrónico porque se baseava no espírito teológico, também o seriam as propostas demoliberais e socialistas: as primeiras, porque radicavam numa abstracção metafísica - o indivíduo - e numa ideia artificial sobre a origem da sociabilidade política; e as segundas, porque não relevavam o papel social da propriedade privada e o cariz natural da família. Além do mais, se ambas tinham sido úteis na demolição da sociedade teológico-feudal e militarista, a sua crítica, por se inspirar em princípios metafísicos, não teria aptidão para substituir o que destruía. De onde promanava a permanente crise das sociedades europeias desde o século XviıI.

Estes considerandos ajudam a entender por que é que Comte, se admirava Hobbes, não aceitava as teses do contrato social - em particular, as de Rousseau e Locke - que fundamentavam os conceitos de soberania popular e de soberania nacional. Se houve um período em que, historicamente (séculos XVII e XVIII), aqueles tinham sido necessários, a sua sobrevivência, na época da vitória definitiva da ciência (que se estava a estender aos fenómenos sociais), seria nociva, dado que prolongava a ilusão metafísica de que o

${ }^{51}$ Cf. Fernando Catroga, "Os inícios do positivismo em Portugal. O seu significado político-social”, Revista de História das Ideias, vol. 1, 1977, pp. 301-303.

${ }^{52}$ Cf. A. Comte, Système de politique positive, T. ${ }^{\circ}$ II, Paris, Librairie Philosophique de Ladrange, 1852, pp. XIII, XVI, XXIX.

53 Cf. Pierre Arnaud, Le "Nouveau Dieu". Préliminaires à la politique positive, Paris, J. Vrin, 1973, pp. 291-308.

${ }^{54}$ Em 1855, A. Comte lançou um Appel aux conservateurs. 
homem, qual Deus na terra, possuiria um livre-arbítrio absoluto em relação às leis da natureza e da sociedade.

Como organicista social e anti-individualista convicto, o filósofo francês pugnou, sobretudo nas obras da sua segunda fase (Système de politique positive), por uma reorganização científica da sociedade que, ao pôr a sociologia a iluminar a acção política, traria a "morte" da própria política. A objectividade da previsão garantiria a futura integração dos conflitos, quer pela racionalidade das influências tidas por científicas, quer através do reforço do sentimento colectivo fomentado pelas práticas simbólicas da nova religião que ele mesmo fundou: a religião da humanidade. Assim se passaria da fase metafísica e crítica para a fase positiva, orgânica e, por conseguinte, sintética. Não mais haveria lugar para surpresas revolucionárias, e a extensão ecuménica deste consenso iria permitir a concretização paulatina, através do progresso na ordem, do sonho iluminista da paz perpétua.

Neste horizonte, o poder temporal devia ser entregue aos que possuíssem capacidade científico-industrial (os industriais e, sobretudo, os banqueiros), enquanto o poder espiritual caberia aos portadores desse conhecimento na sua dimensão mais teórica, universal e altruísta: os filósofos positivistas. Bem vistas as coisas, Comte seguia a hierarquia dual teorizada por Santo Agostinho, secularizando-a: os seus seguidores, quais novos apóstolos, deviam inspirar um plano educativo finalmente cientificado e um novo culto da religião da humanidade ${ }^{55}$, tendo em vista socializar a subordinação do egoísmo ao altruísmo.

A estrutura da sociedade não podia radicar no indivíduo-cidadão, ou no sistema representativo demoliberal: só a ditadura dos saberes realizaria o ideal respublicano de bem comum ${ }^{56}$. É certo que, como em Marx, se enfatizava a crise que tinha nascido da Revolução Francesa e do desenvolvimento industrial. Mas, se se invocava o progresso humano, também se sugeria a entrega do poder, provisoriamente, ao sector social que designava por proletariado. Como este trabalhava para outrem, teria

\footnotetext{
${ }^{5}$ A. Comte, Catéchisme positiviste, Paris, Garnier-Flammarion, 1966, pp. 42 ss.

${ }^{56}$ Cf. Jorge Lagarrigue, La Dictature républicaine d'après Auguste Comte, Paris, Apostolat Positiviste, 1888.
} 
aprendido, na vida prática, o valor do altruísmo. Porém, depois dessa fase de transição, passar-se-ia, definitivamente, para um regime republicano e ditatorial governado pelo capitalismo bancário, com o apoio dos industriais ${ }^{57}$.

A cientificidade geraria o consenso, pelo que a principal liberdade a salvaguardar seria a liberdade de expressão, condição necessária para que os possuidores do saber verdadeiro conseguissem, mediante a livre discussão, vencer o erro veiculado pelas concepções teológicas e metafísicas ou pelas suas misturas ${ }^{58}$. No fundo, Comte desejava "concilier irrévocablement la dictature et la liberté, suivant le voeu systématique de Hobbes, spontanément réalisé par Frédérique"59. Para tal, o Estado devia ser forte, centralista e intervencionista, em ordem a que a propriedade privada desempenhasse uma função social útil, maneira de criticar a reactualização liberal do velho princípio romanista do jus utendi et abutendi romano.

A chamada a terreiro desta variante ditatorial não se deve tanto aos seus efeitos práticos taxativos, mas mais ao facto de ela ilustrar bem a renovação do velho conúbio entre o saber e o poder - cujo último exemplo se encontrava na relação do filósofo iluminista com o déspota esclarecido -, agora celebrado sob os auspícios da ciência social posta ao serviço, não da revolução (como em Marx), mas de interesses conservadores. Não se nega que alguns dos discípulos mais ortodoxos de Comte propagandearam o ideal sociocrático um pouco por todo o lado. No entanto, a alternativa, mesmo nos seus exageros, merece ser destacada, pois constitui uma das mais explícitas críticas à democracia e ao liberalismo feitas, contra as formas sufragadas de legitimação, a partir de autoproclamadas competências científico-técnicas, preconceito que terá várias encarnações até aos dias de hoje.

\section{III}

\footnotetext{
57 Cf. A. Comte, Système de politique positive, T. ${ }^{\circ}$ III, p. 602 ss; T. ${ }^{\circ}$ IV, pp. 345-350. Cf. Pierre Arnaud, ob. cit., pp. 345-350.

58 Cf. idem, ibidem, T. ${ }^{\circ}$ III, p. 602.

${ }^{59}$ Idem, ibidem, T. ${ }^{\circ}$ IV, p. 378.
} 


\section{A EXCEPÇÃo e A REgra}

O papel da ditadura soberana na génese dos Estados-Nação modernos ficou sublinhado, mas a experiência histórica também revela que a possibilidade do seu regresso permanecia inscrita, implícita ou explicitamente, no novo ordenamento político-jurídico. Na verdade, para se fazer face a rebeliões ou a invasões, este previa uma espécie de ditadura à romana. No entanto, quando a excepcionalidade se transformou em regra - como aconteceu no constitucionalismo monárquico e na prática política da I República -, desencadeou-se um significativo debate acerca dos abusos que estavam a ser cometidos quanto ao entendimento das condições de necessidade e de urgência que davam licitude à solução.

\section{A ditadura extraordinária e a ditadura ordinária}

Aqui, limitar-nos-emos a sintetizar alguns dos contornos deste debate e a assinalar as suas implicações políticas, recordando que o tema das ditaduras ganhou maior relevância nos inícios do século xx com a agudização da crise do sistema monárquico (bem patenteada na segunda ditadura de João Franco) e com o prolongamento da querela à volta das formas de representatividade política. Contudo, como o problema era bem mais geral, as discussões internas espelhavam debates externos. Daí que, quer professores universitários como Alberto dos Reis, José Tavares e Marnoco e Sousa, quer conhecidos membros da magistratura (com doutrina expressa em diversos acórdãos de 1907), quer, ainda, publicistas e políticos republicanos (como Basílio Teles, Afonso Costa) lhe tivessem dado particular atenção.

Por exemplo: no ano lectivo de 1909-1910, Marnoco e Sousa ensinava que a ditadura (constituída) governava por decretos-lei (ou, na terminologia de influência alemã, por ordenanças de necessidade) e que tinha de respeitar certos requisitos, a saber: as condições de necessidade ou de urgência que, efectivamente, exigiam providências que não podiam esperar pela deliberação do Parlamento; a competência que este tinha para tomar essas procidências, visto elas terem carácter legislativos; o exercicio tem- 
porário das funções legislativas pelo executivo ${ }^{60}$. No entanto, na linha de Guido D'Amario ${ }^{61}$ e de Alberto dos Reis, também frisava que, desta combinatória, podiam resultar dois tipos ditatoriais: as ditaduras extremas e as ordinárias ou comuns ${ }^{62}$, com graus de legalidade distintos.

Em concreto, a ditadura extraordinária dizia respeito a matéria constituinte ${ }^{63}$, porque estava coberta pelo art. $145^{\circ}, \S 34$ da Carta, em função do qual, por iniciativa do poder legislativo ou, na ausência deste, do executivo - quando aquele não estivesse reunido -, podiam ser dispensadas algumas das formalidades que garantiam as liberdades individuais, em ordem a rapidamente se fazer face a actos de rebelião ou a invasão que pusessem a pátria em perigo. Todavia, a excepção devia cessar logo que se desse o regresso à normalidade, momento em que as medidas entretanto tomadas teriam de ser justificadas perante o poder legislativo. E a suspensão provisória da garantia dos direitos individuais não só tinha um âmbito temporário, como não acarretava a suspensão da Constituição, tanto mais que seria contraditório que esta previsse tal possibilidade em relação a si própria. Daí o fundo "comissarial" desta ditadura extrema, ilação que, porém, não contemplava a possibilidade histórica de a ditadura extraordinária poder evoluir para "ditadura soberana".

No plano teórico, estava-se perante uma "ordinanza d'urgenza" (e de necessidade) prevista na norma, mas de aplicação somente justificável, dentro

\footnotetext{
${ }^{60}$ Cf. Marnoco e Sousa, ob. cit., pp. 745-746.

${ }^{61}$ Cf. Guido D'Amario, L'Ordinanza d'urgenza per lo stato di diritto nelle forme di governo a regime libero-costituzionale con speciale riferimento al diritto pubblico italiano, Turim, Fratelli Bocca, 1907.

${ }^{62}$ Cf. Alberto dos Reis, Organização judicial. Lições feitas ao curso do $4 .^{\circ}$ ano jurídico de 1908 a 1909, Coimbra, 1909, p. 41 ss.

63 "A ditadura ordinária implica o exercício da função legislativa ordinária; a ditadura extrema implica o exercício da função legislativa constituinte, recaindo por isso sobre matéria constitucional”. Não existem dúvidas de que, no primeiro caso, se está, na linguagem de Carl Schmitt, perante o tipo de "ditadura comissária". E o mesmo se poderá dizer da "ditadura extrordinária”, pois o seu poder de suspensão temporária de direitos individuais também está igualmente previsto no poder constituído, ao contrário do que acontece com as "ditaduras soberanas", (também na acepção de Schmitt). Cf. António de Araújo e Miguel Nogueira de Brito, Para a história da fiscalização da constitucionalidade em Portugal. Comentário ao Acórdão de 23 de Julbo de 1907. Supremo Tribunal de Justiça, p. 5, nt. 4 (www.estig.ipbeja.pt/ as)
} 
de certas condições ${ }^{64}$, quando perigasse a segurança do Estado. Em síntese: aquela prevenção constitucional somente dizia respeito a matéria que alguns (como o jurista brasileiro Pimenta Bueno) ${ }^{65}$ remontavam à prática da ditadura republicana à romana, mas que, na opinião de outros (Barthélemy-e-Saint-Hilaire, Benjamin Constant), deveria ser controlada, se não mesmo evitada, pelos ordenamentos constitucionais de inspiração liberal. De qualquer modo, e tal como os seus congéneres modernos, os textos constitucionais portugueses (Constituição de 1822, arts. 211. ${ }^{\circ}, 124 .^{\circ}$, n. $^{\circ}$ IV; Carta Constitucional ${ }^{66}$, art. $^{\circ} 145 .^{\circ} \S \S 33$ e 34; Constituição de 1838, art. 32..$^{\circ}$, com pequenas discrepâncias entre si, contemplaram essa excepcionalidade provisória. E o mesmo fará a Constituição republicana de 1911 (art. 26.).

Por outro lado, não restam dúvidas de que ela seria tanto mais constitucional quanto mais, no imediato, a sua aprovação emanasse do poder legislativo. E as prevenções liberais em relação à sua ocorrência - e aos perigos que esta podia espoletar - explicam que a Constituição vintista, no seu art. $211^{\circ}$, estipulasse que a dispensa de algumas formalidades relativas à prisão dos delinquentes só pudesse ser feita por decreto especial das Cortes. Contudo, como as crises podiam eclodir em conjunturas em que o poder legislativo, por férias ou por dissolução, não estava em funcionamento, as duas Leis Fundamentais posteriores (a Carta Constitucional e a Constituição de 1838) reconheceram capacidade legiferante ao executivo, pelo menos nas condições previstas pelo $\S 34$ do art. $145^{\circ}$ da Carta. E estas obrigavam que todas as decisões legislativas do executivo, entretanto tomadas, recebessem um bill de indemnidade, isto é, uma ulterior aprovação parlamentar.

A ditadura ordinária também tinha um cariz comissarial, mas com um suporte mais polémico, porque o seu objecto recaía "sobre matéria legisla-

\footnotetext{
${ }^{64}$ Jogando com outros artigos da Carta, Silvestre Pinheiro Ferreira havia sustentado que, de acordo com o $\$ 34$ do art. $145^{\circ}$, as autoridades só de dia e de maneira que a lei determinar podiam entrar, por força, na casa de qualquer morador; e que, exceptuando os casos declarados na lei, e nos de flagrante delito, ninguém podia ser preso sem culpa formada. No entanto, na prática, as coisas serão bem distintas. Cf. Lopes Praça, Direito constitucional portuguez. Estudos sobre a carta Constitucional de 1826 e Acto Addicional de 1852, vol. 1, Coimbra Imprensa Litteraria, 1878, pp. 146-147.

65 Acerca do articulado similar, inserto na Carta Constitucional brasileira, invoca a máxima Dent operam consules, ne quid respublica detrimenti capiat.

66 Seguia o art. $^{\circ} 179, \S \S 34$ e 35 da Carta Constitucional brasileira.
} 
tiva não constitucional, envolvendo, por isso, somente o exercício do poder legislativo ordinário"67. Embora fosse usual, esta modalidade não estava isenta de polémica, já que, para alguns, os poderes moderadores do Rei previstos na Carta (art. $71^{\circ}$ ) e o facto de a prática ditatorial se ter tornado uma praxe não bastavam para conferir legalidade aos seus decretos, controvérsia em que também se invocou a história do constitucionalismo europeu. E como, em 1907, lembrava o jurista italiano Guido D'Amario ${ }^{68}$, esta ensinava que, se todas as Constituições previam a ditadura extraordinária, nem todas permitiam ditaduras ordinárias: algumas consentiam-nas, outras toleravam-nas, enquanto outras as interditavam sem ambiguidades.

Quanto às primeiras, citava-se a velha Constituição da Prússia e de outros antigos Estados alemães, onde tinha vingado uma justificação baseada na urgência e na necessidade de se garantir a manutenção da segurança pública. Todavia, o executivo não podia legislar quando o Parlamento estava em funcionamento, ou quando as suas ordenanças atentassem contra a Constituição. $\mathrm{E}$ os decretos saídos em ditadura teriam de receber o bill de indemnidade na primeira sessão do poder legislativo que se reunisse após a sua promulgação. Consequentemente, estava em causa uma excepcionalidade constituída, pois "excluía a ditadura sobre matéria constitucional, embora na prática se tenha afirmado frequentemente sobre impostos" 69 .

Outras Constituições eram mais lacunares, limitando-se a tolerar as excepções. Estaria nessas condições o constitucionalismo histórico inglês, em particular após a aprovação do bill of rights (3 de Fevereiro de 1689) e do reconhecimento de que, em determinadas circunstâncias, o Rei podia utilizar faculdades excepcionais para lhes fazer face. Contudo, embora se tivesse prometido legislar sobre a matéria, tal nunca aconteceu, o que fez arreigar uma prática que se transformou num costume: de o Parlamento ter de examinar as providências ditatoriais em cada caso, a fim de as legalizar mediante o bill de indemnidade ${ }^{70}$.

\footnotetext{
${ }^{67}$ Marnoco e Sousa, ob. cit., p. 746.

${ }^{68}$ Cf. Guido D'Amario, ob. cit., pp. 31-40.

${ }^{69}$ Marnoco e Sousa, ob. cit., p. 750.

${ }^{70}$ Idem, ibidem; Guido D'Amario, ob. cit., pp. 53-60.
} 
Para os que, nos séculos Xix e inícios de Novecentos, vieram a fazer uma aplicação continuada deste instituto, lembrava-se a parcimónia e os limites da sua aplicação. Com efeito, foi contra os excessos cometidos durante os estados de excepção e a sua metamorfose em (quase) regra que Marnoco e Sousa citava o grande jurista Albert Venn Dicey (professor em Oxford e renomado autor da obra Introduction to the study of the law and constitution, 1885) para sublinhar que, na Grã-Bretanha, nunca se tinha suspendido o habeas corpus por um decreto ditatorial. Por outro lado, com a intenção de atingir os que queriam elevar o costume a fonte do direito constitucional português, o professor de Coimbra avançava com este argumento jurídico: enquanto as providências ditatoriais não forem assumidas como leis pelo poder legislativo, somente existiria "um estado de facto, ilegal, não jurídico, cuja responsabilidade pesa inteiramente sobre o governo do Rei tolerado pelo costume"71. Esta tese não só vinha ao encontro da defesa da divisão dos poderes, como, naquele contexto, pretendia atacar os apologistas da supremacia do "poder governamental" sobre o poder legislativo, tendência que tinha alcançado o seu ponto máximo com a segunda ditadura de João Franco.

Outras Constituições iam mais longe na rejeição da ditadura comum ou ordinária. E dava-se como exemplo a Carta Constitucional francesa de 1830, ao declarar, no seu art. $6^{\circ}$, que o Rei não detinha a faculdade de suspender a lei ou dispensar a sua execução por meio de decretos ou regulamentos. Levado à letra, isto queria dizer que a regularização do estado de facto criado pela ditadura só acontecia quando o Parlamento elaborasse "novas leis, em que se encontrem contidas as providências ditatoriais”. Neste contexto, a que família constitucional pertenceria a Carta portuguesa?

Sublinhe-se que, para além do preceituado para o governo das Províncias Ultramarinas. (como o previsto no art. $137 .^{\circ}$ da Constituição de 1838), a única excepção, no plano legal, relativamente à proibição constitucional dos decretos com força de lei, encontra-se no art. 6. ${ }^{\circ}$ do decreto ditatorial de 25 de Setembro de 1895, que atribuía ao Rei, no exercício do poder moderador, a faculdade de "promulgar decretos com força legislativa", quando

\footnotetext{
${ }^{71}$ Marnoco e Sousa, ob. cit., p. 752. Cf. Guido D'Amario, ob. cit., p. 35 ss.
} 
houvesse divergências entre a Câmara dos Deputados e a Câmara dos Pares, não resolvidas pela comissão nomeada para o efeito. ${ }^{72}$

Marnoco e Sousa compartilhava com Alberto dos Reis este diagnóstico: "a ditadura comum é evidentemente ilegítima, segundo a Carta Constitucional", já que o poder executivo somente poderia exercer funções legislativas no âmbito da ditadura extrema ou extraordinária, isto é, nas estritas condicionalidades previstas no $\S 34$ do seu art. $145^{\circ}$. Ir mais além implicaria o incumprimento da separação dos poderes e o desrespeito dos arts. 13. ${ }^{\circ}$ e $15^{\circ}, \S 6$ da Carta, que definiam o poder legislativo como a única instância com competências para fazer leis, interpretá-las, suspendê-las e revogá-las; o Rei somente tinha o poder de as vetar ou sancionar. Além do mais, o exercício de funções legislativas, por parte do executivo, também estaria em contradição com o previsto no art. $75^{\circ} \S 12$ : não podendo expedir decretos que contrariassem as leis, ele somente deteria a competência de publicar decretos e regulamentos para a sua boa execução, pois, "se assim não fosse, chegaríamos à conclusão de que a Constituição admitia a função legislativa dupla e antinómica, apesar do absurdo que tal doutrina envolve"73. Deste modo, também não valia o argumento dos que aceitavam a produção legislativa do executivo em ditadura, desde que ela só incidisse sobre matéria não legislada.

É um facto que estas interpretações não eram dominantes no seio do poder judicial, para quem, se era certo que, em circunstâncias excepcionais, o poder executivo, ao promulgar providências ditatoriais, invadia a órbita legislativa, a fiscalização e a censura políticas sobre esse acto de usurpação não lhe pertenceriam, mas às Cortes. E estas, com o bill de indemnidade, confirmavam a legalidade dos decretos-lei através da fórmula: "continuam em vigor".

Por outro lado, os prosélitos da ideia segundo a qual o estado de necessidade "é a suprema razão do direito" sustentavam que "é a urgência que

\footnotetext{
72 Joaquim Gomes Castilho, Direito Constitucional e Teoria da Constituição, 6. ed., Coimbra, Almedida, 2002, pp. 787-788.

73 Marnoco e Sousa, Direito Político. Poderes do Estado, pp. 755, 763.
} 
justifica a ditadura, imprimindo força legal aos respectivos decretos". E, mesmo que este estatuto não estivesse estipulado em "textos expressos", a sua plena constitucionalidade proviria do "direito consuetudinário"74 em uso, pelo menos, desde 1832 (legislação de Mouzinho da Silveira). O principal teorizador desta argumentação foi José Tavares.

\section{A supremacia do "poder governamental"}

Para aquele jurista, não havia dúvidas: não só os decretos das ditaduras ordinárias tinham legitimidade constitucional, como a ditadura em si mesma seria um recurso politicamente útil quando comparado com o monopólio legislativo do Parlamento. Significa isto que fazia uma leitura antiparlamentarista da Carta Constitucional, perspectiva que reforçava com a invocação de especificidades idiossincráticas que aconselhavam o recurso a ditaduras com duração alargada. Tavares recorria à lição positivista e organicista para se escudar com a lição dos factos da "vida social e política", e a sua ideia de ditadura só não era comtiana porque era monárquica e porque não a projectava como definitiva. De qualquer modo, e como o seu adversário Basílio Teles, também tinha subjacente os presumidos ditames do evolucionismo social para defender que ela "representa uma função política necessária e essencial em todos os Estados de civilização imperfeita, em que os elementos sociais não estejam preparados e suficientemente educados para o funcionamento normal do regime democrático representativo" 75 .

Pensando bem, o que aqui estava em causa dizia somente respeito à ditadura ordinária. No entanto, também não se tratava de um posicionamento circunscrito ao debate acerca da força de lei dos decretos ditatoriais. A sua argumentação jurídica estava carregada de juízos de valor políticos, apostados em justificar a predominância do poder executivo sobre o legislativo e a redução deste último ao papel de mero órgão vigilante da

\footnotetext{
${ }^{74}$ José Tavares, O Poder governamental no direito constitucional portuguez. Lições para o curso do 2. ${ }^{\circ}$ anno de Direito no mez de Maio de 1909, Coimbra, Imprensa Académica, 1909, pp. 179-180.

${ }^{75}$ Idem, ibidem, p. 190.
} 
acção legisladora dos governos. Para aí apontavam quer as necessidades e urgências do país, quer o sentido da evolução histórica. E, segundo este, o Parlamento estaria em decadência, pois havia "chegado até à mais completa incompetência legislativa, conseguindo apenas manter, mas ainda assim sem critério e sinceridade, a sua mais própria e útil função, que é a de fiscalizar constantemente o funcionamento dos outros poderes políticos" 76 .

Em função destes pressupostos, entende-se que o autor das lições sobre O Poder Governamental, ecoando antigas conotações ligadas à palavra "ditadura", enfatizasse a grande utilidade das ditaduras ordinárias e contestasse aqueles que a viam como "um regime político inadmissível, representando o regresso ao antigo regime (...). A ditadura não é a tal vontade arbitrária, autoritária ou despótica do Governo; não é tal a opressão de quaisquer liberdades, quer públicas, quer particulares".

Seria esse o estatuto da ditadura extraordinária, tal qual estava previsto no $\S 34$ do art. 145 . $^{\circ}$ da Carta. Aquelas, porém, conquanto significassem um "exercício temporário e provisório da função legislativa pelo próprio Governo, quando o Parlamento se mostra incapaz de satisfazer urgentes necessidades sociais", deviam ter uma duração maior. De qualquer modo, não deixava de reconhecer que pertencia à "própria natureza da ditadura" ser não só "provisória e condicional", como estar "sempre sujeita ao voto imediato do Parlamento". De onde inferia que "a instituição, ao contrário das declarações dos demagogos, é eminentemente prática e essencialmente liberal"77. Via-a, assim, como um meio conducente à aceleração das medidas reformadoras que se impunham, incluindo a do sistema representativo, que devia caminhar para uma base mais marcadamente orgânica. E as implicações políticas deste debate ficarão mais bem esclarecidas se se lembrar que José Tavares, então professor da Faculdade de Direito da Universidade de Coimbra, foi um acérrimo defensor do franquismo, mesmo depois de Fevereiro de 1908.

\footnotetext{
${ }^{76}$ Idem, ibidem.

77 José Tavares, ob. cit., pp. 190-191.
} 


\section{As propostas de "acalmação" constitucional}

Por outro lado, o entendimento da posição dos juristas académicos ganha se igualmente se relevar o contexto da agitação antifranquista, incluindo a contestação (1907) ao ensino ministrado na Faculdade de Direito. Ora, os juízos então lançados, sendo justos na generalidade, podem obstar a que se esteja atento às clivagens que também existiram no seio daquela instituição, mormente acerca do tema das ditaduras. Basta dizer que a tese de Tavares, se visava os "demagogos" republicanos (e, em particular, Afonso Costa e os governos monárquicos da "acalmação"), também não poupava alguns dos seus colegas e, sobretudo, os monárquicos não-franquistas Alberto dos Reis e Marnoco e Sousa. É que, sem sofismas, estes conclamavam contra a ilegalidade e, portanto, a inconstitucionalidade de boa parte do ordenamento jurídico em que assentava a Monarquia Constitucional.

Demais, numa obra de defesa da Faculdade contra os ataques de que era alvo, aqueles dois docentes não deixaram de assinalar as implicações políticas do seu ensino. Assim, o livro destacava não só a sua luta a favor do respeito da divisão dos poderes, como frisava que, numa época em que a instituição era acusada de "reaccionária e indiferente às violações jurídicas”, Alberto dos Reis, nos seus cursos e na obra Organização judicial, analisava o candente problema da eficácia dos decretos ditatoriais, para demonstrar "a ilegitimidade da chamada ditadura comum em relação ao Continente e Ilhas, deduzindo-se daí, para o poder judicial, a obrigação de se recusar a aplicar os decretos ditatoriais"78. Posição que, por sua vez, Marnoco aprofundará, contra Tavares, nas lições sobre teoria política que ministrou no ano lectivo de 1909-1910 79 .

Relativizando o peso dos costumes como fonte de direito público, salientavam, ainda, que a origem da Lei Fundamental portuguesa não estava no constitucionalismo histórico, mas nos pressupostos das constituições escritas de matriz predominantemente francesa. Aceitar o direito consuetu-

\footnotetext{
${ }^{78}$ Marnoco e Sousa e Alberto dos Reis, A Faculdade de Direito e o seu ensino, Coimbra, França Amado, Editor, 1907, pp. 81-82.

${ }^{79}$ Cf. Marnoco e Sousa, Direito Político. Poderes do Estado, pp. 759-760.
} 
dinário a este nível seria negar que a vontade nacional continuasse com capacidade para inovar e revogar o direito e não perceber que, em Portugal, não existia a conjugação de factores que, de acordo com Guido D'Amario ${ }^{80}$, davam eficácia jurídica ao costume: a continuidade, a espontaneidade e a consciência de se criar direito. E eles faltavam porque "em todas as ditaduras, tanto o Parlamento ao aprová-las, como o governo ao executá-las, tinham a convicção de que elas representavam um excesso". Por isso, concluía Marnoco e Sousa, a posterior aprovação parlamentar das providências ditatoriais decorria mais de razões de "oportunidade política e algumas vezes por causa dos benefícios reais que delas derivavam” do que da aceitação da coexistência de duas instâncias com capacidade legislativa ${ }^{81}$.

Não admira, assim, que esta perspectiva também pusesse a nu uma insuficiência da Carta: a inexistência de uma instância que, em última análise, julgasse a constitucionalidade das leis e, em particular, as decretadas pelo poder executivo que, sem pronúncia parlamentar, entravam imediatamente em vigor. Colmatar esse vazio já teria sido a intenção da lei de 1 de Agosto de 1899, que reconhecia a necessidade de se reformar a Carta Constitucional (nomeadamente o seu art. 119. ${ }^{\circ}$ ), em ordem a dar-se competência aos juízes para negarem cumprimento aos decretos ditatoriais, intento explicitado na legislatura seguinte, por proposta de 14 de Março de 1900. Porém, a leitura que prevalecerá sobre esta legislação irá em sentido diferente: a imediata entrada em vigor, com força de lei, dos decretos saídos em ditadura ordinária não sofreriam de inconstitucionalidade, conforme defendeu o célebre acórdão do Supremo Tribunal de Justiça exarado em 23 de Julho de 1907. No entanto, e descontando a argumentação lançada pelos grupos políticos de oposição (republicanos, monárquicos dissidentes), as posições como as de Alberto dos Reis e Marnoco e Sousa ficaram menos isoladas após a queda de João Franco.

Com efeito, em Agosto de 1909, o então ministro da Justiça e Cultos, Francisco José Medeiros, apresentou no Parlamento um projecto relativo à organização judiciária, cujo § único do art. 1. ${ }^{\circ}$ constituía uma autêntica "proi-

\footnotetext{
${ }^{80}$ Guido D'Amario, ob. cit., p. 42.

${ }^{81}$ Marnoco e Sousa, ob. cit., p. 758; Alberto dos Reis, Organização Judicial, p. 55 ss.
} 
bição legal das ditaduras" 82 . Na verdade, aí se declarava que "não têm força de lei, e por isso a ninguém obrigam, os decretos do poder moderador, que não forem promulgados nos termos da Constituição; os regulamentos, instruções e decretos do poder executivo contrários à lei, e também os promulgados por ele com excesso da respectiva autorização legal, ou arrogando-se atribuições do poder legislativo, salvos os casos restritos e precisos dos $\S 33$ e 34 do artigo $145^{\circ}$ da Carta Constitucional e do artigo $15^{\circ}$, $\S \S 1$ e 2 da lei constitucional de 5 de Julho de 1852, e bem assim as próprias leis ordinárias opostas a disposições constitucionais, como as define o artigo 144 . $^{\circ}$ da mesma Carta" ${ }^{3}$.

Juntamente com esta exigência cresceu a da necessidade de se legislar sobre a responsabilidade ministerial na imposição administrativa das disposições decretadas em ditadura. O sinal mais relevante nesse sentido veio da proposta de lei apresentada à Câmara dos Deputados (6 de Outubro de 1906) por José de Abreu Couto Amorim Novais, ministro da Justiça do primeiro governo de João Franco (formado para governar à inglesa). De acordo com o seu art. $5 .^{\circ}$, os ministros passariam a ser responsáveis pelo abuso do poder nas seguintes circunstâncias: quando, no atinente aos direitos individuais, havia suspensão das leis constitucionais fora dos casos previstos no $\S 34$ do art. $145 .^{\circ}$ da Carta Constitucional; quando, fora deste caso, as leis constitucionais, ou quaisquer leis, eram suspensas com usurpação da função das Cortes; e quando o poder executivo revogava ou reformava as leis constitucionais, ou quaisquer outras, com usurpação de atribuições que pertenciam exclusivamente ao poder legislativo ${ }^{84}$. A medida não impediu que a reivindicação se tivesse mantido no decurso da República, pelo menos até 1914.

A questão da responsabilidade ministerial e da constitucionalidade da imediata entrada em vigor dos decretos promulgados em ditadura surgia

\footnotetext{
${ }^{82}$ Luís Bigotte Chorão, Política e Justiça na I República. Um regime entre a legalidade e a excepção, vol. 1: 1910-1915, Lisboa, Letra Livre, 2011, pp. 51-52.

83 Diário da Câmara dos Senhores Deputados da Nação Portuguesa, n. ${ }^{\circ}$ 45, 11 de Agosto de 1909, p. 33. (Daqui para a frente, DCSDNP.)

${ }^{84}$ DCSDNP, n. ${ }^{\circ}$, 6 de Outubro de 1906, p. 20; Marnoco e Sousa, ob. cit., p. 762.
} 
condicionada por um problema bem mais profundo, a saber: o dos limites do uso da função moderadora do Rei, sob pena de se cair no funcionamento desequilibrado dos poderes decorrente da banalização do recurso à ditadura ordinária. Com efeito, como esta impunha uma primazia do executivo ancorada na decisão régia, na prática isso significava que a legitimidade de origem sacro-hereditária do poder do Monarca se sobrepunha à que tinha a sua fonte no cidadão eleitor. E a prova máxima desta distorção estava na prática comum da dissolução, da governação em ditadura e no modo como se garantia a alternância política. Atente-se a estes últimos aspectos.

Como se sabe, a Carta Constitucional (art. $74 .^{\circ} \S 4$ ) atribuía ao poder moderador a faculdade de dissolver a Câmara dos Deputados quando a salvação do Estado o exigisse, obrigando-o a convocar imediatamente outra que a substituísse. No entanto, para que a duração do provisório não se prolongasse indefinidamente, o Acto Adicional de 1885 tinha determinado que, após a dissolução, as novas Cortes deviam ser convocadas e reunidas dentro de três meses. Além disso, não poderia haver nova dissolução sem ter passado uma sessão de igual período de tempo. Porém, o Acto Adicional de 1896 - já filho do impacto da doutrinação de Oliveira Martins - mudou as coisas: o poder moderador continuava com capacidade para dissolver o Parlamento, mas não previa qualquer prazo constitucional para convocar outro que o substituísse (art. 6. $\$ 2$ ). Daí que Marnoco e Sousa, fazendo o balanço dos efeitos da última ditadura de João Franco, não tivesse dúvidas: "este sistema deu os piores resultados, contribuindo para o engrandecimento do poder real, que tão nefasto foi à monarquia" 85 . Com esta posição, o professor de Direito aprofundava as críticas dos que, situando-se no campo monárquico, tinham em vista provar o cariz usurpador da ditadura ordinária.

Retomando a contestação aos que, para defenderem a supremacia do poder executivo sobre o legislativo, invocavam a plena legalidade constitucional da produção legislativa das ditaduras, o professor de Direito (ministro

\footnotetext{
${ }^{85}$ Marnoco e Sousa, Constituição Política da Republica Portuguêsa. Commentario, Coimbra, França Amado, Editor, 1913, p. 503.
} 
do último governo de "acalmação") reafirmava, nas vésperas da República, a tese que, em 1907, Guido D’Amario havia expendido para o caso italiano: nem o estado de necessidade e de urgência, nem a sua função supletiva face ao não legislado pelo Parlamento seriam argumentos suficientes para conferir o estatuto de lei aos decretos ditatoriais. E a sua posição, tal como a de Alberto dos Reis, era firme: de acordo com os arts. 15. ${ }^{\circ}$, 6 e 75.', $\S 12$ da Carta, só as Cortes podiam fazer leis, interpretá-las, suspendê-las e revogálas, ficando ao poder executivo unicamente reservada a faculdade de publicar normas e regulamentos para a boa execução das leis ${ }^{86}$.

De onde esta outra ilação: "da fórmula usada de que as medidas ditatoriais continuam em vigor", não se podia concluir que antes "tivessem força legislativa e obrigatória. Com esta fórmula pretende o poder legislativo ratificar as providências ditatoriais, não só para o futuro, mas também para o passado". Mas também as podia rejeitar, situação que, porém, nunca ocorreu, porque as novas maiorias parlamentares, formadas após as dissoluções, foram sempre das cores dos governos ditatoriais que organizaram as eleições. Consequentemente, "enquanto os decretos ditatoriais não são aprovados no Parlamento, mediante o bill de indemnidade, esses decretos são actos ilegais, sem nenhuma eficácia jurídica”, ficando a sua imediata aplicação a dever-se ao facto de a ditadura ordinária ser imposta como ditadura administrativa, pois o governo tinha "mil meios de dar execução aos decretos ditatoriais, valendo-se da acção subordinada dos seus agentes e funcionários" 87.

Neste contexto, explica-se que alguns monárquicos pensassem que o regime só sobreviveria se tivesse coragem para introduzir reformas que reequilibrassem o funcionamento da divisão de poderes. E, na opinião de Marnoco, tais medidas teriam de cumprir este objectivo essencial: respeitar as funções do poder legislativo, corrigir a deriva do engrandecimento do poder real, tornar efectiva a responsabilização ministerial e eficaz a vigilância do poder judicial sobre a inconstitucionalidade das leis.

\footnotetext{
${ }^{86}$ Idem, Direito Político. Poderes do Estado, p. 763.

${ }^{87}$ Idem, ibidem, p. 760.
} 
Mais especificamente, no campo do poder legislativo, seriam meios eficazes de impedir as ditaduras comuns a reunião das Câmaras por direito próprio e a eliminação do estabelecido no terceiro Acto Constitucional (art. $7^{\circ}$ ), segundo o qual, quando as leis de receita e de despesa não tinham sido votadas até ao fim do ano, se determinava que continuassem em vigor, no ano imediato, as últimas disposições legais sobre essa matéria.

No tocante ao poder executivo, seria necessário promulgar uma boa lei sobre a responsabilidade ministerial, que considerasse os actos ditatoriais como abuso do poder, e que, na linha de uma proposta que o dissidente José de Alpoim tinha avançado, não punisse a não-observância das disposições dos decretos ditatoriais.

Sobre o poder judicial, Marnoco reiterou a sua posição anterior: ele devia estar constitucionalmente proibido de aplicar os decretos ditatoriais, tese muito enfatizada por Guido D'Amario e em relação à qual os republicanos não podiam estar mais de acordo. De facto, o jurista italiano era taxativo: "Il potere giurisdizionale adunque non può e non deve riconoscere ad un'ordinanza d'urgenza forza obbligatoria di leggere per la razione unica e vincente che l'ordinanza d'urgenza è un illegato atto di governo" 88 .

Por outro lado, propunha que o poder moderador funcionasse com mais restrições. Assim, e no que concerne ao direito de dissolução, achava que se devia voltar ao determinado pelo Acto Adicional de 1885, isto é, ao prazo de três meses para a eleição e a convocação do novo Parlamento, não podendo haver uma outra dissolução sem passar uma sessão parlamentar de igual período de tempo ${ }^{89}$. Com tudo isto, Marnoco e Sousa estava convencido de que estas condições seriam suficientes para acabar, definitivamente, com "qualquer tentativa ditatorial no nosso país"90.

Como se vê, algumas destas ideias podiam ser perfilhadas por todos os que tinham contestado o poder franquista. Outras, porém, eram bem distintas das defendidas pelos republicanos, dado que não punham em causa

\footnotetext{
${ }^{88}$ Guido D’Amario, ob. cit., p. 205.

${ }^{89}$ Marnoco e Sousa, ob. cit., pp. 764-765.

${ }^{90}$ Idem, ibidem, p. 765.
} 
nem o regime, nem o poder moderador, nem o direito de dissolução, pressupostos que os Constituintes de 1911 irão rejeitar.

\section{A reforma republicana do constitucionalismo monárquico}

Com efeito, aos republicanos convinha toda a argumentação que ajudasse a pôr em causa a Monarquia e, em particular, a excepcionalidade a que esta tinha recorrido, por norma, para construir o núcleo duro da sua estrutura político-administrativa. E quando, na conjuntura em causa, começaram a pensar em alternativas constitucionais, não se forçará a nota afirmar que elas denotam uma espécie de "complexo cartista" na sua formulação, incidência claramente materializada na recusa, por boa parte dos activistas do movimento, da eleição directa do Presidente da República e do direito de dissolução, bem como na aceitação do cariz parlamentarista do futuro regime. Daí que o seu alvo principal fosse conseguir mudar o regime e, ao mesmo tempo, impedir as ditaduras que extravasassem os estritos limites da necessidade de se constitucionalizar a chamada ditadura extrordinária.

Compreende-se. A média duração das práticas ditatoriais comuns tinha provocado esta dupla consequência: o partido que, mantendo-se no poder ou vindo da oposição, organizava as eleições, nunca as perdia; e, dentro das duas grandes famílias políticas do constitucionalismo monárquico, era visível que o Monarca tendeu a privilegiar a corrente menos progressista, ou melhor, o Partido Regenerador e os seus avatares. Tudo isto, conjugado com a crise financeira e com a degradação dos costumes políticos, não deixou de contribuir para o aumento da contestação ao modo como se estava a interpretar as funções do poder moderador, polémica que redobrou quando, em ditadura, o executivo procurou resolver questões que seriam próprias do poder legislativo (como foi o caso dos polémicos adiantamentos financeiros à Casa Real). Em simultâneo, o uso da dissolução e da ditadura ordinária também revelava que a alternância política - que devia resultar do normal funcionamento do sistema - estava a ser garantida por via administrativa, o que, se merecia a firme oposição das forças antidinásticas, também descontentava os sectores monárquicos que se sentiam 
preteridos. E, com o agudizar da crise na primeira década de Novecentos, o crescimento da incapacidade de integração dos sectores das elites políticas preteridas pelo sistema fez medrar os fraccionamentos partidários e, até, as conspirações, como a aliança de dissidentes monárquicos com os republicanos, em Janeiro de 1908, bem revela.

O posicionamento mais claro dos republicanos sobre as matérias em apreço encontra-se no célebre discurso que Afonso Costa fez no Parlamento, em 19 de Maio de 1908, com o intuito de fundamentar um compromisso político tendente a introduzir reformas na Carta Constitucional que bloqueassem a possibilidade de a "nova Monarquia" pós-franquista poder voltar à ditadura. E, como outros críticos do abuso deste instituto, o deputado propunha uma espécie de tréguas seladas à volta de um compromisso re-formista que tinha em vista tornar impossíveis as práticas que, no seu modo de ver, eram inconstitucionais.

Para ele, os atropelos à divisão de poderes tinham sido uma prática corrente no decurso da Monarquia Constitucional, e "a invasão mais grave da função legislativa foi feita pelas ditaduras", sobretudo a partir de 1890, ano da "primeira ditadura do engrandecimento do poder real, durante o qual não houve qualquer reunião das Cortes" ${ }^{91}$. Sustentada por uma interpretação abusiva da função moderadora do Rei e pelos interesses dos chefes partidários que alimentavam o jogo das alternâncias de poder, a ditadura ordinária tinha sido imposta administrativamente com a conivência da magistratura. Porém, para Afonso Costa, "nem a frouxidão dos velhos partidos, nem as subserviências de juízes caducos" poderiam realizar "o milagre de fazer útil ou profícua a ditadura, mesmo para os seus autores. Sobretudo para eles!" 92 . Por isso, aconselhava o novo governo de "acalmação" (chefiado por Ferreira do Amaral) a trilhar um caminho diferente, pois o facto de as ditaduras se terem tornado numa "matéria tão corrente no nosso meio político e social” dava força à previsão segundo a qual não estaria longe "a hora em que a nova Monarquia se sentirá tentada a voltar a elas". Daí o

\footnotetext{
${ }^{91}$ DCSDNP, n. ${ }^{\circ} 12,19$ de Maio de 1908, p. 17

${ }^{92}$ Idem, ibidem.
} 
aviso: "ditadura é como a porta do Inferno de Dante. Quem uma vez ali entrou, tem de perder toda a esperança de voltar para trás"93.

Tacticamente, o deputado republicano fazia acompanhar este diagnóstico por uma proposta de pacificação na luta à volta da questão do regime. $\mathrm{E}$, entre outros pontos, avançava com a ideia de se proceder a uma reforma da Carta (ou à elaboração de uma nova Constituição) que eliminasse as causas que tinham gerado a normalidade da excepção, mormente o poder de dissolução, o servilismo da burocracia e a passividade do poder judicial face ao julgamento da legalidade dos decretos ditatoriais. Mais em concreto, ter-se-ia de aprovar: a "proibição de dissolver as Cortes"; a "reunião por direito próprio e com garantias materiais eficazes"; a "proibição a todos os funcionários de recolherem impostos que não hajam sido votados pelo Parlamento"; a "proibição aos juízes de aplicar quaisquer decretos do poder executivo, que vão além da boa execução das leis; a responsabilidade dos Ministérios simplificada, e como que automática”. Estas seriam as providências mínimas a acordar entre republicanos e monárquicos antifranquistas, a fim de se apagar os "abusos do reinado anterior "e de se não" continuar ou recomeçar os maus costumes então introduzidos" 94 . E, em certa medida, aqui ficavam esboçadas algumas das ideias que se tornarão dominantes aquando da discussão, em Junho-Agosto de 1911, do perfil da nova Lei Fundamental republicana.

Por outro lado, a proposta também revela que Afonso Costa estava em sintonia com aqueles que queriam pôr a magistratura a julgar a constitucionalidade das leis, opção que entroncava no exemplo pioneiro dos Estados Unidos e que a Constituição republicana do Brasil (de 24 de Fevereiro de 1891) tinha seguido nos seus arts. 59. ${ }^{\circ}$ e 60. . Não por acaso, esse poder será explicitamente constitucionalizado em 1911. Com efeito, pelo art. 63. ${ }^{\circ}$ da Constituição republicana, "o Poder Judicial, desde que nos feitos submetidos a julgamento, qualquer das partes impugnar a validade da lei ou dos diplomas emanados do Poder Executivo ou das corporações com autoridade pública, que tiverem sido invocadas", iria

\footnotetext{
93 Idem, ibidem. Cf. Luís Bigotte Chorão, ob. cit., p. 42

${ }^{94}$ DCSDNP, n. ${ }^{\circ} 12,19$ de Maio de 1908, p. 17.
} 
apreciar "a sua legitimidade constitucional ou conformidade com a Constituição e princípios nela consagrados". Com isto, Portugal inovava na Europa.

Em resumo: quer nos argumentos que irão justificar a opção pelo modelo parlamentar contra o presidencialista, quer na escolha da eleição indirecta do Presidente da República e na redução do seu cargo a um papel quase simbólico, quer na recusa do direito de dissolução (fosse por iniciativa parlamentar ou presidencial), quer na atribuição ao poder judicial da fiscalização da constitucionalidade das leis, quer na criminalização da responsabilidade ministerial, quer, ainda, na quase taxativa proibição da ditadura comum, é possível surpreender o peso, por via negativa, de um forte "complexo cartista" na modelação da Lei Fundamental republicana. E este preconceito também se surpreende na ênfase que foi posta na componente parlamentarista do novo regime, tanto mais que esta característica estaria a ser um sucesso na III República francesa. Porém, nem todos os republicanos pensavam assim, embora muito poucos ousassem porpor, explicitamente, a via ditatorial como o melhor meio para se implantar e, sobretudo, consolidar a República.

\section{A ditadura "positivista" de Basílio Teles}

A necessidade de a futura República instaurar uma ditadura, a fim de se ultrapassar a decadência a que a Monarquia teria conduzido o país, já tinha sido propagandeada por um republicano federalista ${ }^{95}$ próximo das correntes radicais francesas. Referimo-nos a Felizardo Lima ${ }^{96}$. No entanto, foi Basílio Teles quem melhor adaptou a lição política de Comte à terapêutica da crise da sociedade, quando, em 1907, fundamentou o programa que teria de ser trilhado para que, em Portugal, a política entrasse, final-

\footnotetext{
95 Cf. Fernando Catroga, O Republicanismo em Portugal. Da formação ao 5 de Outubro de 1910. 3. a ed., Lisboa, Casa das Letras, 2010, p. 56, nota 62.

${ }^{96}$ Cf. Felizardo Lima, A Solução nacional, Porto, Typographia Gutenberg, 1892.
} 
mente, na sua era científica97. Porém, e como José Tavares - mas com finalidades opostas -, o publicista portuense tinha um conceito positivo de ditadura, não só por razões teóricas, mas também pelo facto de, "pela sua frequência e duração", ela ter "já entrado no domínio dos nossos hábitos políticos"98. Daí que, sem subterfúgios, escrevesse que a solução podia ser "o meio único, ou, entretanto, o mais eficaz e rápido de implantar reformas de incontestável alcance colectivo", tanto mais que constituía "uma fórmula resolutiva não só útil, mas até inevitável, no conflito eventual entre indicações contraditórias, desconexas, deficientes ou vagas, embora legalmente expressas" pela opinião pública99. Além do mais, só com uma coerente e continuada política de reformas o novo regime se enraizaria numa sociedade em que o povo era analfabeto e estava tutelado pelo clericalismo. Ora, se alguns republicanos achavam que, após a queda da Monarquia, se tinha de instaurar uma "ditadura inicial", e não se opunham ao recurso a uma "ditadura eventual" ou extraordinária em caso de ataque às instituições, o mesmo não acontecia quanto ao prolongamento indeterminado da excepção. Qual o tipo de ditadura que Basílio tinha em mente?

Como é lógico, via-a "como um processo muito legítimo e defensável de exercitar o poder em diversas conjunturas anormais" e encarava-a como um episódio essencialmente "transitório (porque uma ditadura em permanência seria, propriamente, o absolutismo)"100. Por isso, também lhe reconhecia o cariz excepcional e provisório, embora, quanto a esta última característica, não determinasse a sua duração, requisito que se coadunava bem com a índole soberana e constituinte, ou melhor, revolucionária da ideia que propugnava. Com tais objectivos, percebe-se que a sua proposta

\footnotetext{
97 Cf. Pedro Miguel Páscoa Santos Martins, Basílio Teles (1856-1923). As faces de Jano da modernidade, Braga, Universidade do Minho, 2007, pp. 339-422 (edição mimeografada); Manuel Villaverde Cabral, "Basílio Teles: o nacionalismo republicano, do decadentismo ao autoritarismo", in Prelo, n 15 , Abril-Junho, 1987, pp. 19-33; Luís Salgado de Matos, "Basílio Teles", in O Tempo e o Modo, n. 36, Março, 1966, pp. 336-358.

98 Basílio Teles, As Ditaduras. O regime revolucionário, Coimbra, Atlântida, 1975, p. 12.

${ }^{99}$ Idem, ibidem, p. 14.

${ }^{100}$ Idem, ibidem, p. 15.
} 
não se reduzisse à ditadura comum, nem à ditadura extraordinária frequentes na Monarquia. Ia mais longe, já que, pensada como ditadura soberana, teria de ser concretizada por novas formas de articulação entre o poder e os cidadãos. A sua fonte inspiradora estava na génese da I República francesa e tinha como pano de fundo o sociologismo de Comte, geminado, porém, e ao contrário do que acontecia com os positivistas heterodoxos da III República e seus seguidores portugueses, com a crítica à representação política alicerçada no indivíduo-cidadão, bem como aos seus fundamentos (a soberania popular ou nacional) e às suas mais directas consequências: o parlamentarismo e a divisão dos poderes.

É indiscutível que, em geral, todo o positivismo forneceu argumentos às campanhas contra ao cariz ecléctico do constitucionalismo monárquico e contra a cultura política da sua elite. Esta, frequentemente acusada de pedancrota, não estaria à altura das circunstâncias por causa das filosofias teológicas ou metafísicas que perfilhava e devido à sua impreparação no domínio das ciências sociais, insuficiência que seria directamente proporcional ao manejo de uma retórica aprendida nos bancos da Universidade e exercitada na demagogia parlamentar. Explica-se, assim, que - e na linha do exemplo dominante na III República francesa (Littré, Gambetta, Jules Ferry) - o acasalamento do positivismo com o republicanismo tivesse passado por apropriações heterodoxas e sincréticas, em ordem a escamotear-se o antiparlamentarismo, o antiliberalismo e o antidemocratismo de A. Comte.

Em qualquer dos casos, mesmo quando os ensinamentos de Saint-Simon ou de Comte não implicaram a defesa directa da sociocracia, o certo é que eram manejados como arma de credibilização do mérito que possuiria quem os convocava. Como se assinalou, em Portugal, esta idealização vinha das últimas décadas do século XIX, onde começou a ser arremessada contra o sistema representativo de inspiração liberal ou democrática. Esta atitude engrossará sob a I República, período em que, com o crescimento da instabilidade política e social, aparecerá ainda mais irmanada com projectos autoritários e ditatoriais de vária origem ${ }^{101}$. E Basílio Teles também não

\footnotetext{
101 Cf. Miguel António Dias Santos, Anti-liberalismo e contra-revolução na I República, Coimbra, Faculdade de Letras, 2009; Luís Bigotte Chorão, A Crise da República e a Ditadura Militar, pp. $219-372$.
} 
deixa de ser um sintoma desta tendência mais longa, a que o fracasso do parlamentarismo republicano dará novas reactualizações.

Devido a razões que se prendiam com a psicologia colectiva do povo português e com os ditames da evolução social, Basílio sustentava que, em Portugal, a República só se radicaria através de uma "ditadura revolucionária" que não se cingisse à fase da tomada do poder ("ditadura de entrada"), ou à presumível "ditadura eventual”, talvez necessária para se fazer face aos inevitáveis movimentos contra-revolucionários que o seu advento suscitava. Mas, aos que ansiavam pela rápida constitucionalização do regime, aconselhava a meter "o sufrágio em pousio"102. Em qualquer dos casos, avisava que o prolongamento da "ditadura revolucionária" só não se transformaria em tirania se o novo poder soubesse lançar um conjunto coerente de reformas, determinadas "por considerações elevadas, de natureza social", e não por "predilecções egoístas de temperamento e vantagens mesquinhas de facção”. Se o fizesse, conseguiria conquistar a opinião pública e, assim, garantir o consentimento para o exercício de uma ditadura indeterminada ${ }^{103}$, que não seria despótica devido ao facto de a autoridade, posta ao serviço da coisa pública, estar em harmonia com a liberdade.

Poder-se-ia mesmo dizer que dos seus efeitos iria nascer um regime que já não mereceria o título de ditadura na acepção rigorosa do termo, "não só por ser permanente", mas também por "ter recebido o assentimento geral dos cidadãos", por não impedir "a legítima liberdade do poder judicial" e por ser "modificável e perfectível"104. Em suma: Basílio acreditava que, com os resultados de uma governação dirigida para a felicidade geral, com uma reorganização do sufrágio baseada em critérios sociológicos, e com a participação, a par do escol possuidor de competências, das "classes" e "colectividades", os sociocratas receberiam o reconhecimento dos cidadãos, "por virtude da conhecida gratidão dos povos para com os homens que mais talento, mais saber e mais tenacidade e desinteresse têm revelado na difícil tarefa de transformar vagas

\footnotetext{
102 Basílio Teles, ob. cit. p. 26.

${ }^{103}$ Idem e ibidem, p. 15.

${ }^{104}$ Idem e ibidem, p. 27.
} 
aspirações em conquistas sociais positivas"105. Porém, como se devia exercer este processo ditatorial provisório até à sua substituição por um regime permanente? E qual o ditador que estaria "à altura do papel"106 transitório que Basílio Teles lhe atribuía?

Este não aceitava formas personalizadas de ditadura, fossem monárquicas ou republicanas. E, se atacava "o engrandecimento do poder real", não deixava de sublinhar que "toda essa obra de reacção" não constituía uma "divisa exclusiva do sr. Franco (...) só por ele exclusivamente proclamada, e traduzida em leis e resoluções governativas". Se fosse assim, ficaria sem explicação o facto de, sob a Monarquia Constitucional, se ter "vivido e revivido em contínuo regime de ditadura, ostensiva ou disfarçada"107.

O seu modelo também não era o da experiência romana, com a sua encarnação individual e a sua transitoriedade definida, finda a qual se regressava à situação anteriormente constituída. Esse seria o caso das ditaduras extraordinárias previstas nas Constituições. Mas também não mais faria sentido apelar-se à intervenção do grande homem morigerador. É que as sociedades modernas, devido à maior complexidade das suas estruturas, à orientação vaga e contraditória das suas aspirações e ao "enfraquecimento da personalidade humana", já não conseguiriam "produzir uma dessas soberbas criaturas a quem os romanos voluntariamente confiavam a direcção suprema do Estado, todas as vezes que um perigo sério ameaçava, ou não chegavam a entender-se sobre algum ponto de importância"108.

A ditadura de Basílio seria constituinte, de gestão colectiva e, portanto, sem individualização. Percebe-se. Para se perseguir o bem geral da coisa pública, o seu exercício não podia estar subordinado a interesses pessoais, de facção, de partido ou de classe. Assim, por maior que venha a ser a sua admiração por Lenine, a ideia de uma ditadura de classe estava nos antípodas da idealização do papel de vanguarda que atribuía às

\footnotetext{
${ }^{105}$ Idem, ibidem, p. 26.

${ }^{106}$ Idem, ibidem, p. 19.

${ }^{107}$ Idem, ibidem, pp. 10, 11.

${ }^{108}$ Idem, ibidem, pp. 19-20.
} 
elites a quem reconhecia méritos, morais e científicos, para governar a sociedade.

Por outro lado, a sua ideia de ditadura, enquanto sintoma da debilidade dos sistemas representativos clássicos, aparecia estreitamente ligada a uma filosofia da história de cunho evolucionista, que invocava para prognosticar a inevitável ultrapassagem do parlamentarismo, inaugurado pela centenária experiência britânica e, depois, assimilado pelas teorias do contrato social e da divisão de poderes. Repugnava-lhe a autonomia (e supremacia) do poder legislativo em relação aos demais, e é indiscutível que a sua alternativa apontava para o reforço do executivo. De onde entender por ditadura "a acumulação dos poderes executivo e legislativo numa única entidade, parlamento ou gabinete".

Simpatizava com o perfil das ditaduras encarnadas num colectivo, uma espécie de entidade política, às vezes materializada por uma assembleia (um longo Parlamento, a Convenção, por exemplo), outras, como acontecia mais frequentemente, por um gabinete ${ }^{109}$. E tudo leva a crer que, para o caso português, Basílio (apesar de não ser muito explícito) se inclinava para esta última via. Por sua vez, ao escrever numa conjuntura em que mesmo alguns monárquicos se empenhavam em demonstrar a ilegalidade das $d i$ taduras ordinárias e dos decretos-lei que produziam, tinha consciência de que, em relação às ideias perfilhadas pela maior parte dos seus correligionários, estava a remar contra a aceitação de uma ditadura meramente provisória, de curta duração e encarada como trânsito para uma República que queriam constitucionalizar de acordo com os princípios da representação demoliberal e parlamentarista. Daí lastimar que o ideário da maior parte dos seus correligionários continuasse imbuído de "ortodoxia democrática" e que lhes confessasse, sem sofismas: "sim, amigos, sou partidário irredutível das ditaduras" $" 110$.

A opção pela tomada violenta do poder (forte a partir de Abril de 1909) virá a colocar o problema da ditadura no cerne da transição a percorrer entre a queda da Monarquia e a institucionalização do novo regime. Mas

${ }^{109}$ Cf. Idem, ibidem, pp. 15, 20.

${ }^{110}$ Idem, ibidem, p. 190. 
o caminho que será seguido será bem diferente do proposto por Basílio Teles. Seguir-se-á o já traçado pelos exemplos em que a implantação de Repúblicas surgiu como remate constitucional de "ditaduras soberanas" provisórias escoradas numa legitimidade revolucionária que queria aprofundar, a partir dos direitos e deveres individuais, a representação nacional. E não se pode esquecer que, em termos portugueses, esse já havia sido o percurso que conduziu às duas Leis Fundamentais que os constituintes de 1911 invocarão como precursoras: a de 1822 e a de 1838.

\section{A ditadura, segundo Salazar}

Quando ocorreu o advento da Ditadura Militar (28 de Maio de 1926), várias tinham sido as experiências ditatoriais que, em nome da excepção, procuraram justificar-se com a necessidade e a urgência de se responder a situações de crise. Com um cariz mais extraordinário ou mais ordinário, todas foram implantadas em nome da salvação da Pátria e da República. Foi o caso das chamadas ditaduras de Pimenta de Castro e de Sidónio Pais. Todavia, se a primeira parece enquadrar-se, pelo menos no que respeita aos seus objectivos mais explícitos, no âmbito das funções da ditadura republicana à romana, a segunda, instaurada na sequência de um golpe de Estado, queria ir mais longe, já que almejava constituir uma República Nova. Por sua vez, o aparecimento de outras modalidades de ditadura soberana (a revolução russa de 1917, a ascensão do fascismo italiano e a ditadura de Primo de Rivera em Espanha) veio enriquecer a panóplia das ofertas autoritárias, mesmo antes do impacto de teorizações importantes sobre elas, como era aquela que Carl Schmitt começava a publicitar.

Ora, não será novidade afirmar que um sector que participou no movimento de 28 de Maio, se tinha ideias claras sobre o que não queria, estava longe de um consenso no que respeita ao passo que se devia dar quando a urgência e a necessidade deixassem de justificar o prolongamento da excepção. E se, nos inícios, alguns se contentavam com a reforma da Constituição de 1911, outros, porém, estavam sobretudo interessados em aprofundar o seu estatuto soberano, aplicando-o à criação de um novo or- 
denamento jurídico político. Como é sobejamente sabido, Salazar foi hegemonizando a sua liderança no seio desta última corrente.

Ele aproveitou a intervenção que fez, a propósito da passagem do $4 .{ }^{\circ}$ aniversário do golpe militar, para defender que a Ditadura Militar não podia ser uma ditadura administrativa (extraordinária ou ordinária), estatuto a que os adversários a queriam reduzir. Se o fosse, concluída a sua tarefa, "nada mais haveria a fazer do que restabelecer a ordem constitucional, suspensa ou violada desde 28 de Maio de 1926"111. E, conquanto somente mencionasse os "inimigos" da situação, também visava os que, no seu interior, pensavam que a intervenção das forças armadas devia cessar com uma reforma que possibilitasse a morigeração das práticas político-partidárias anteriores, como se bastasse substituir a elite partidária sem mudar as estruturas que tão deficientemente a tinham gerado.

Contrariando estas ideias, Salazar empenhou-se em mostrar que a Ditadura Militar, após as hesitações iniciais, passou a agir como força constituinte de uma realidade política nova, de um "Estado Novo" ${ }^{112}$. E, tendo apreendido na vulgata do sociologismo organicista mais compatível com a doutrina social da Igreja (Leão XIII) que os fenómenos sociais - embora com autonomia ${ }^{113}$ se correlacionavam entre si, chamava a atenção para este facto: toda a administração tem de ser comandada por uma política, desde que esta seja entendida na sua acepção mais nobre. Como a vida em sociedade radicava no desempenho de várias funções concomitantes, uma proficiente ditadura teria de "obter o estabelecimento de condições políticas, administrativas, económicas, sociais e de cultura susceptíveis de garantir, por uma verdadeira revolução, o renascimento da Nação Portuguesa"114. De onde o dever de

111 Salazar, Discursos, vol. 1, 4. ${ }^{a}$ ed., Coimbra, Coimbra Editora, 1948, p. 61.

112 Sobre o pano de fundo em que, já antes, tinha aparecido esta expressão, bem como acerca da voga da ideia de "novo" na retórica política portuguesa, leia-se Luís Reis Torgal, Estado Novo, Estados Novos, vol. 1, Coimbra, Imprensa da Universidade, pp. 70 ss.

113 Com efeito, desde a década de 1880, tinha-se desencadeado, na Faculdade de Direito da Universidade de Coimbra, um debate acerca da divisão e hierarquização interna das funções e fenómenos sociais (e respectivos domínios científicos), no seio da sociologia. Cf. Fernando Catroga, "O sociologismo jurídico e as suas incidências curriculares. 1837-1911", in Actas do Congresso História da Universidade, vol. 1, Coimbra, Universidade de Coimbra, 1991, pp. 399-414.

${ }^{114}$ Salazar, ob. cit., p. 141. 
se inspirar "numa doutrina económico-social, se quereis mesmo, uma filosofia", bem como este aviso: "ai dos governos, melhor, ai dos povos cujos governos não podem definir os princípios superiores a que obedece a administração pública que fazem"115.

Por sua vez, em lição aprendida na escola, também sabia que toda a ditadura provoca a concentração de poderes e o enfraquecimento da fiscalização do seu uso, o que, em sua opinião, desembocava na opressão e no arbítrio (e, tacitamente, na tirania e no cesarismo), possibilidade que cresceria com a sua perpetuação. Por isso, àqueles outros que não estavam de acordo com a constitucionalização da Ditadura Militar, recordava que, como toda a solução ditatorial "é essencialmente uma fórmula transitória", não seria "bom que a si mesmo se proponha a eternidade"116. Porém, sendo um caminho sem regresso à situação anterior, para onde devia caminhar?

Quatro anos depois, e já com a Constituição de 1933 polemicamente plebiscitada - não houve liberdade de oposição e as abstenções contaram como votos a favor -, esclareceu melhor não só a sua recusa das ditaduras meramente suspensivas da norma, como os elos que deviam persistir entre a ditadura política e o poder que ela constituía. Assim, em discurso proferido a 26 de Maio de 1934, voltou a atacar os que sonhavam (ou tinham sonhado) confiná-la a um intermezzo regenerador do sistema demoliberal. Alertava: "terão inteiramente perdido o seu tempo os que voltarem atrás, como talvez também o percam os que nelas supuseram encontrar a suma sabedoria política". Nem eternas (como estes últimos almejariam), nem regressivas, mas "experiências com larguíssima influência nos regimes futuros", a transitoriedade das ditaduras desaguaria numa constitucionalização assente em novos fundamentos, porque, opinava Salazar, elas "não me parecem ser hoje parêntesis dum regime", porque são "elas próprias um regime, se não perfeitamente constituído, um regime em construção"117. Deste modo, não poderia haver um hiato entre a Ditadura Militar e a Constituição, como aconteceria caso esta fosse elaborada por uma Assembleia Constituinte,

115 Idem, ibidem, p. 62.

${ }^{116}$ Idem, ibidem, p. 64.

${ }^{117}$ Idem, ibidem, p. 346. Os itálicos são nossos. 
eleita a partir do indivíduo-cidadão. Dito de outro modo: se muitas ditaduras provisórias assumiram que a constitucionalização que se the seguia significava a sua "morte", na do Estado Novo pretendia-se institucionalizar a própria ditadura, metamorfoseada em Estado autoritário. Bem vistas as coisas, esta evolução está confirmada no teor de uma das respostas que, em 1933, Salazar deu a António Ferro: com a nova Constituição não acabaria a ditadura em si, mas somente ocorria "o fim da ditadura na sua forma actual"118. Como Salazar estava longe, no que, neste momento (e não em matéria financeira), terá aprendido nas citadas obras de Alberto dos Reis e de Marnoco e Sousa. Afinal, e descontadas as diferenças de conjuntura e o desenvolvimento de uma ideia mais totalizadora de ditadura, em termos portugueses, o seu posicionamento tem mais afinidades do que com as teses de José Tavares e de Basílio Teles do que com as dos seus dois antigos mestres.

A precisão que fez convida a supor que a nova ordem também devia ser encarada como um meio conducente ao reforço do "poder governamental", isto é, à necessária subalternização do poder legislativo ao poder executivo, no quadro de um Estado forte. Simultaneamente, se parecia negar a excepção (com a teórica garantia dos direitos fundamentais do cidadão), prolongava-a através quer das medidas previstas para o estado de sítio, quer das restrições que a lei positiva impunha ao usufruto da liberdade de pensamento, expressão e associação.

Por sua vez, é indiscutível que, no pensamento de Salazar deste período - que, silenciada a queda da experiência de Primo de Rivera, o sucesso das ditaduras em Itália e na Alemanha parecia empiricamente comprovar -, o regime em construção (autoritário, orgânico, corporativo e nacionalista) reivindicava uma irreversibilidade prognosticada como fim da história. Deste modo, mesmo algumas das concessões que a Constituição de 1933 fez à representação "republicana" (eleição da Assembleia Nacional pelos cidadãos eleitores; eleição do Presidente da República por sufrágio directo) teriam uma validade meramente transitória. Confessou-o em 1934, ao profetizar que, "dentro de vinte anos, a não se dar qualquer processo de evolução política,

\footnotetext{
${ }^{118}$ In António Ferro, Salazar. O bomem e a sua obra, Lisboa, Empresa Nacional de Publicidade, 1933, p. 139.
} 
não haverá na Europa assembleias legislativas"119, ou, ainda, ao afirmar que "a democracia julga que os seus princípios são imutáveis, que se podem aplicar em todos os tempos, em todos os lugares e em todos os acontecimentos. Mas nós não acreditamos que a História se repita, que seja um itinerário obrigado, que depois da democracia venha a super-democracia!"120. E este convencimento provinha da perfilhação de um certo positivismo mitigado (relembre-se que o tradicionalismo e o integralismo dos inícios do século xx também se tinham posto sob os auspícios de uma unilateral leitura de Comte), mormente no atinente à elevação do modelo organicista de sociedade a fonte inspiradora da alternativa autoritária e corporativa. Percebe-se: o organicismo, caldeado com o historicismo, podia servir de argumento contra o individualismo, em nome de um consenso definitivo a atingir quando o Estado conseguisse pôr o ordenamento político de acordo com a índole orgânica da nação.

Ora, se esta afirmação enfatizava algo que a prática política estaria a patentear, pelo menos, a partir da I Guerra - o reforço do poder executivo face ao legislativo -, também queria significar que só um regime autoritário poderia integrar as conflitualidades sociais e responder, célere e de um modo planificado, à crise de valores morais e sociais anómicos, perigo que o impacto da revolução comunista tinha reforçado. Por tudo isto, a ditadura não devia ser constituída mas constituinte. E, como a sociedade era uma totalidade - certeza já antiga em Salazar -, ela só seria regeneradora se fosse "totalitária", isto é, se soubesse concretizar uma política global.

Recorde-se que, em 1930, Salazar já foi explícito acerca do modo como a Ditadura Militar - que tinha no exército "o andaime necessário à construção da obra, à construção do Estado Novo"121 - devia resolver o problema político português: normalizá-la como "regime", "por meio de uma obra educativa que modifique os defeitos principais da nossa educação, substitua a organização à desorganização actual e integre a Nação,

\footnotetext{
119 Salazar, ob. cit., p. 381.

${ }^{120}$ In António Ferro, ob. cit., p. 68.

${ }^{121}$ In idem, ibidem, p. 33.
} 
toda a Nação, no Estado, por meio de um novo estatuto constitucional"122. Por conseguinte, a construção jurídico-política, económica e social de um novo regime ${ }^{123}$ só seria duradoura se, movida por elites competentes e despartidarizadas (o velho sonho dos meritocratas), houvesse força para realizar uma revolução cultural inspirada num ideal que encarasse a nação como uma entidade psicocolectiva perene, cuja vocação idiossincrática estaria plasmada no melhor da sua história. Só assim se conseguiria que "o Estado fosse a expressão da Nação na sua vida colectiva"124.

Pensando bem, esta ditadura, não obstante ser soberana, também se considerava comissária de uma realidade que lhe seria preexistente e que a trespassaria, ao atribuir à nação a posse de uma soberania omnipresente que, perante a ameaça da sua dissolução, as forças armadas, como em outros momentos de crise, tomaram nas suas mãos. E essa seria a base legitimadora da governação por decretos-lei, pois essa Ditadura Militar seria sinónimo de Ditadura Nacional. E, se a sua constitucionalização em 1933 recuperou o princípio segundo o qual "a soberania reside essencialmente em a nação", o certo é que não lhe deu uma interpretação liberal, muito menos contratualista, mas orgânica ${ }^{125}$. É que a nação devia ser a forma,

122 Salazar, ob. cit., p. 65. Os itálicos são nossos.

123 Neste contexto, Salazar não utilizava o termo "regime" para qualificar a opção entre República ou Monarquia. Independentemente das suas preferências pessoais (para muitos, elas iriam para esta última), aceitou a primeira como uma realidade de facto. E fê-lo por razões pragmáticas e de princípio, a saber: à luz da doutrina social da Igreja, a questão seria secundária; as suas críticas não iam somente contra a República parlamentar e laica, mas também contra a Monarquia Constitucional, e desconfiava do politique d'abord dos integralistas; pensava que empolar o problema do regime seria dar força ao republicanismo radical e dividiria o campo dos republicanos conservadores, com peso nas forças armadas e, portanto, na Ditadura Militar; sentia-se ligado ao compromisso, que selou com estas, no sentido de não se mexer na fórmula republicana. Por palavras suas: "O problema do regime embaraça e envenena a marcha dos governos em Portugal, dos governos da direita, principalmente. Há que pô-lo de lado (...). Evitando todas as manifestações e declarações que possam fazê-lo renascer na primeira oportunidade" (p. 22). Além do mais, confessou: "Quando o Exército me convidou a fazer parte do Governo, pôs-me o problema da Nação acima do problema das instituições, defendendo, por isso mesmo, o regime existente. Concordei, aceitei e é essa a minha insofismável posição" (in António Ferro, ob. cit., pp. 22-24).

${ }^{124}$ Salazar, ob. cit., p. 37.

125 Para uma síntese histórica da constitucionalização do princípio da soberania nacional de 1822 a 1933 , leia-se Fernando Catroga, "Em nome da nação", in F. Catroga e Pedro T. de Almeida, ob. cit., pp. 20-59. 
a alma do Estado. Porém, para que não continuasse o divórcio entre ambos, seria necessário ultrapassar o individualismo e dar representação às sociedades intermédias, embora inscrevendo as suas relativas autonomias numa cadeia de comando de cunho hierárquico, pois, "por sobre as fracções de poder (...) o Estado estenderá o manto da sua unidade, do seu espírito de coordenação e da sua força: deve o Estado ser tão forte que não precise de ser violento" 126.

\section{Da nação orgânica ao Estado uno, autoritário, orgânico e corporativo}

Quer isto dizer que o corporativismo tinha por principais adversários o atomismo social e o estatismo absoluto. Contudo, não desejava ser um eclectismo, já que se propunha fazer, a partir da realidade (e não de abstracções), uma síntese que, criativamente, os superaria. Como se explicava na Câmara Corporativa, em 1955, isto é, numa conjuntura em que, perante o fracasso e o congelamento da corporativização do país, um sector do regime pretendia relançar o modelo, depois dos "desvios" provocados pelo impacto social e económico da II Guerra: "Na verdade, não são apenas dois os sistemas puros de organização social - individualista e socialista -, porque pode demonstrar-se, sem dificuldade, que o sistema corporativo não se identifica com qualquer deles, nem é combinação dos dois. Enquanto no sistema individualista e no sistema socialista a imagem social se exprime por uma criação abstracta da inteligência, que é o binómio Indivíduo-Estado, com o predomínio absoluto de um dos dois termos, na solução corporativa - porque parte da realidade concreta - a imagem da sociedade apresenta-se sob a forma natural e trinómica Indivíduo-Instituição-Estado"127.

Não espanta, assim, que a "estática social", em que o Estado Novo quis alicerçar a sua "revolução", fosse apresentada como uma indução extraída dos "factos", tese que repetia alguns dos lugares-comuns compartilhados, pelo menos desde De Bonald, pelo pensamento conservador e reaccionário

\footnotetext{
${ }^{126}$ Salazar, ob. cit., p. 81.

${ }^{127}$ In Actas da Câmara Corporativa, n. ${ }^{\circ}$ 91, 7.6.1956, p. 868.
} 
antiliberal. E Salazar limitava-se a reproduzir essa cartilha, quando, em 1930, ensinava: "o liberalismo político do século XIX criou-nos o 'cidadão', indivíduo desmembrado da família, da classe, da profissão, do meio cultural, da agremiação económica, e deu-lhe, para que o exercesse facultativamente, o direito de intervir na constituição do Estado. Colocou, por isso, aí a fonte da soberania nacional"128.

Contra esta concepção, o realismo sociológico era posto ao serviço da reactualização da velha ideia de nação orgânica, anti-individualista e anticontratualista, pressupostos que Salazar traduziu deste modo: "a Nação - a nossa Nação - é um todo orgânico, constituída por indivíduos diferenciados em virtude de aptidões diversas e actividades diferentes, hierarquizadas nas suas funções diferentes (...). A família, a sociedade, o sindicato profissional, a associação de fins ideais, a autarquia local" ${ }^{29}$.

É verdade que, amiúde, se reafirmava que o reconhecimento da onticidade específica das sociedades intermédias no seio da sociedade como um todo não conduzia à subsunção do indivíduo; ao invés, eram elas que deviam estar ao serviço da sua realização. Entre outros, apregoou-o o próprio Salazar, mormente ao explicar: "Se eu proclamei e tomei como divisa 'Nada contra a nação; tudo pela nação', não quero com isto dizer que a coloque acima do homem. Pelo contrário, eu considero que este, pela sua alma, espiritualidade e destino, que não se limita a este mundo, é superior à nação e não poderia tornar-se um simples elemento constituinte. Não é preciso reduzir o povo a um formigueiro de seres minúsculos e iguais. Bem longe disso, eu penso que é preciso elevar o indivíduo, desenvolver a sua iniciativa, nunca substituir o Estado ao homem, quando o homem pode agir por si. É pela união, pela conjugação de indivíduos evoluídos e superiores que se consegue formar uma grande nação"130. De onde a apologia do corporativismo autoritário como uma espécie de "terceira via": "Há que contrapor a um e a outro extremo o Estado forte, mas limitado pela moral, pelos princípios do direito das gentes, pelas garantias e liberdades indivi-

128 Salazar, ob. cit., p. 85.

${ }^{129}$ In António Ferro, ob. cit. pp. XXIII-XXIV.

${ }^{130}$ In Diário da Assembleia Nacional, n. ${ }^{\circ}$ 113, 29.01.1937, p. 375. Os itálicos são nossos. 
duais que são exigência superior da solidariedade social"131. No entanto, a coexistência da excepção e da regra na constitucionalização dessas garantias, interligada com o conceito de indivíduo que estava subjacente à doutrina, trazia contradições à lógica do que se dizia querer salvaguardar.

$\mathrm{O}$ indivíduo estaria umbilicalmente ligado às sociabilidades naturais e históricas, modo de ser que ditava a relativização do seu estatuto e fazia diminuir o seu papel como elemento constituinte e legitimador da sociedade política, pelo que a reorganização do Estado teria de espelhar essas estruturas essenciais da nação. É que aquele, não sendo, como Comte tinha defendido, uma mera "abstracção metafísica", não possuiria, porém, a auto-suficiência que as premissas do liberalismo político e da democracia lhe atribuíam. E, na época em que as ditaduras pareciam ser a regra, e não a excepção, Salazar podia explicitar, sem ambiguidades, as diferenças: a "valorização do indivíduo que proclamo e julgo necessária, nada que tem que ver com os chamados Direitos do Homem e refere-se apenas à sua valorização como elemento social. O indivíduo não pode viver sem a colectividade, é certo, mas a colectividade também não é nada sem o indivíduo"132. Só que esta correlação não era horizontal, mas vertical, isto é, hierárquica.

\section{From nation to state, ou from state to nation?}

Do exposto se conclui que a ideia de nação, propugnada pelo Estado Novo, era arremetida contra o conceito demoliberal de "nação cívica". No entanto, também aqui se deve ser cauteloso, porque não são raros os que têm detectado a existência, nos primórdios do regime - e mesmo no interior da Constituição de 1933 -, de um compromisso entre a tradição do republicanismo conservador e a solução corporativa, anti-individualista e autoritária, coabitação que, em termos constitucionais, se traduzirá no recurso a um duplo critério de legitimação (o sufrágio territorial directo e o

\footnotetext{
${ }^{131}$ Salazar, ob. cit., p. 80.

${ }^{132}$ Idem, ibidem, p. 149.
} 
sufrágio indirecto e corporativo) e cuja compreensão exige que se explicite a maneira como os ideólogos do regime - incluindo, antes de todos, o próprio Salazar - faziam a destrinça entre nação ("inorgânica", "orgânica") e Estado. Estariam umbilicalmente ligados. Porém, ter-se-ia de pôr a "nação no Estado", e não colocar este a "fazer" a nação ${ }^{133}$.

Com esta imbricação, encobria-se o trabalho da ideologia a fundamentar esta premissa: todo o Estado correctamente organizado é um "Estado social e corporativo". À luz do preconceito de onde partia, o raciocínio tinha coerência: como a sociedade é um todo, resultante da conjugação do funcionamento específico dos organismos parciais mas correlacionados que o compõem, estes deviam intervir directamente na constituição dos corpos supremos do Estado. Sabe-se que o casamento ente autoritarismo e corporativismo não é uma novidade e, pensando bem, a proposta é uma das variantes da concepção historicista e orgânica de nação, lançada contra o predomínio do ideal de nação cívica. De facto, perante esta opção - "from state to nation", ou "from nation to state" -, a escolha ia para esta última. Mas quais foram os argumentos de Salazar?

Dir-se-ia que, para ele, a nação estaria para o corpo social como a alma estava para o corpo humano. No entanto, a desconstrução desta analogia facilmente detecta o recurso a entidades meta-históricas que contradizem o simultâneo apelo à relevação dos ensinamentos dos "factos". Na verdade, Salazar supunha a "alma nacional" como o omnipresente motor da história pátria, bem como da sua missão histórica, posição que não espanta, vindo de quem pensava a nação como "uma entidade moral" agraciada pela vontade divina. Esta eleição, encarnada por um povo habitante de um território, com fronteiras delimitadas há séculos, ter-se-ia objectivado em grandiosos feitos que deviam ser assumidos, pelos vivos, como uma herança a exigir continuidade e renovamento. Como quem diz: a nação portuguesa não existiu sempre; porém, uma vez no mundo, poderia existir para sempre.

\footnotetext{
133 Sobre todo o processo que levou do Acto Colonial (1930) à Constituição de 1933, veja-se António de Araújo, A Lei de Salazar. Estudo sobre a Constituição Política de 1933, Coimbra, Edições Tenacitas, 2007.
} 
Mesmo que de um modo perfunctório, pode concluir-se que, nesta caracterização salazarista, confluíam a herança aristotélico-tomista e as teorizações historicistas, orgânicas e antidemocráticas que vinham, sobretudo, de Oitocentos e das campanhas contra as teses pactíveis sobre a origem das sociedades políticas. Todavia, na explicitação dos factores condicionantes da índole específica da nação, parece indiscutível que Salazar enfatizou, sobremaneira, o peso da história (contada à sua maneira), sem que isso implicasse a denegação dos agregados naturais e sociais. Recorde-se que o conceito de "raça" era comummente usado nos discursos políticos portugueses desde as últimas décadas do século xıx, em particular nos diagnósticos de orientação decadentista (e, consequentemente, regeneracionista). E se, no contexto da história universal, ela estava imbuída de preconceitos de teor eurocêntrico (e racista), o mesmo não acontecia quando, em termos internos, se qualificavam as suas relações com os demais povos da Europa. Aí, a "raça" referenciava, acima de tudo, a síntese dos factores etnoculturais, históricos e mesológicos, e era invocada mais como prova de decadência do que como argumento reivindicativo de uma superioridade em relação a quaisquer outros povos europeus.

Foi nestes cautelosos limites que Salazar procurou precaver-se contra os excessos da convocação de argumentos racistas (em curso desde o século XIX, em boa parte a partir de uma certa leitura da definição étnica e cultural de povo, dada por autores como Hamann e Herder) praticados pelo nazismo, cujo ideal de nação e de nacionalismo - revalorizador do conceito de Volks estaria diminuído, em sua opinião, "por características raciais tão bem marcadas que impôs, do ponto de vista jurídico, a distinção entre o cidadão e o sujeito - e isso sob o risco de perigosas consequências"134 .

Mais do que um determinismo racial, a nação seria uma entidade moral, com uma diacronia garantida pelo renovamento da herança, isto é, da memória histórica. Porém, os mortos só deviam governar os vivos (Burke, Comte) se estes o não merecessem (Salazar). Por isso, este historicismo não ditava que o passado se sobrepusesse ao presente, mesmo que a ideologia o usasse como prova de uma continuidade histórica que teria uma missão

${ }^{134}$ Salazar, Como se levanta um Estado, Lisboa, Atomic Books, 2007, p. 63. 
a cumprir. É verdade que esta característica foi comum aos processos de afirmação de quase todas as identidades nacionais e, com maior ênfase, àqueles que, explícita ou implicitamente, referenciavam o modelo bíblico de "povo eleito".

Com o que ficou escrito, intenta-se avançar esta ideia: o Estado Novo recuperou boa parte da mitologia que a religião civil portuguesa (centrada na gesta dos Descobrimentos) procurou interiorizar, como memória nacional, pelo menos a partir das últimas décadas do século XIX. No entanto, procurou recatolicizá-la, com o objectivo de travar a laicidade republicana e de lhe dar o complemento de transcendência e de providencialismo que lhe faltava, em ordem a consumar-se esta alquimia, comum ao agir de todos os Estados-nação (mesmo aos que se justificavam como nações-Estado): fazer dos indivíduos, atomizados pela sociedade de massas, um povo consensualizado pelo reconhecimento e compartilha de sentimentos de integração. Mas, se o civismo republicano e laico quis pôr, tal como o seu paradigma francês, o culto da pátria no lugar de Deus, o novo regime, conquanto não menosprezasse o adquirido, colocá-lo-á sob uma declarada protecção divina, fundacionalmente crismada no milagre de Ourique. Di-lo, com toda a clareza, a célebre trilogia "Deus, Pátria e Família”, forma sintética do lema inspirador - o mote "Deus, Pátria, Liberdade e Família", criado pelo escritor brasileiro Afonso Pala, e que tanto impressionou Salazar quando o leu (ainda antes de chegar ao poder) -, mas onde, não por acaso, se fará cair o terceiro termo. Seja como for, trata-se de uma divisa bem distinta da que servia de bandeira ao carlismo espanhol: "por Dios, por la Patria y el Rey"135.

Indiferente à questão do regime (na linha da doutrina social da Igreja, depois de Leão XIII), o doutrinador do Estado Novo impulsionou um projecto político totalizador que, todavia, não pode ser confundido com o sonhado pelo Integralismo Lusitano. Provam-no, por exemplo, as suas opções no terreno político-administrativo. Assim, não obstante a vida paroquial ter ficado sob o governo dos chefes de família e de se ter reconhecido o estatuto, limitado, de autarquia à província (Código Administrativo de 1936-1940),

\footnotetext{
135 A divisa terá sido inventada pelo advogado Antonio Aparisi y Guijarro (1815-1872) e rezava assim: "Dios, Patria, Fueros y Rey".
} 
o cariz igualmente uno e indivisível do novo Estado será ainda mais forte do que o da versão "jacobina" edificada pela Monarquia Constitucional e prolongada pela República. E o mesmo aconteceu aos "patriotismos locais". Recorde-se que estes não estavam vivificados por qualquer participação democrática e que a doutrinação e a propaganda do novel regime fomentavam a sua diluição (ou subordinação) no patriotismo comum e nacionalista. Com efeito, eles serão domesticados quer através da exploração da ideologia ruralista (numa programada folclorização do povo), quer mediante o reforço do matiz nacionalista e imperialista do legado da religião civil de Oitocentos, corrigindo-o e aprofundando-o, porém, no quadro de uma totalizadora e constitucionalizada política autoritária, corporativa, nacionalista e imperial, isto é, no seio de uma planificada "política do espírito" (António Ferro).

Como se salientou, a fundamentação da nova ordem política punha a nação, na espontaneidade da sua vida, a criar o Estado, numa militância assumidamente anticontratualista e antijacobina. Contudo, como nos modelos adversários, nela também se atribuía ao Estado a função última de nacionalizar as almas, por violência directa ou simbólica (educação nacional; livro único; serviço militar obrigatório; religião civil catolicizada; proibição de partidos políticos, etc.), tarefa que, diga-se, os Estados-nação autoritários, e com um estratégia ainda mais totalizadora e inclusiva do que as recuperações demoliberais da herança jacobina, levaram às últimas consequências.

Tudo isto soa, contudo, a uma involuntária confissão de dúvida no que respeita à apregoada perenidade da nação, já que a passagem desta, da essência para a plenitude da sua existência, requeria o artefacto, ou melhor, a acção continuada de uma ordem política forte e vigilante. Seria através do intervencionismo estatal que se realizaria a consubstanciação da nação, pretensamente natural e histórica, numa nação orgânico-corporativa, una e indivisível (do Minho a Timor). Pode sustentar-se que esse já era o projecto consignado nos textos constitucionais portugueses desde a Constituição de 1822. É verdade. No entanto, importa frisar esta diferença: enquanto esta, sem postergar os direitos históricos, privilegiava, em primeiro lugar, a renovação do pacto social, o Estado Novo reivindicava a existência da mesma unidade nacional, multiétnica e sem contiguidade territorial, convocando argumentos de pendor orgânico e historicista. O que significava que, neste 
caso, a ideia de nação se impunha, não como um contrato, mas como uma imperativa herança, ou melhor, como um imutável e inalienável património.

Deste modo, talvez não seja despropositado insinuar que o Estado Novo foi, neste domínio, uma espécie de "jacobinismo", não obstante o seu assumido antijacobinismo. Aliás, sem a pertinência da hipótese será difícil compreender por que é que, apesar das diferenças de fundamentos e de objectivos, é possível encontrar, desde a Monarquia Constitucional e a I República até ao Estado Novo, uma transversal presença de similitudes estruturais na organização político-administrativa do país, bem como no Olimpo da mitologia nacional, tendência de média duração que aquele intentou integrar na sua política totalizadora e autoritária. Por isso, o regime construído na década de 1930 também deve ser visto - embora sem se escamotear as suas especificidades - como uma tentativa para completar, e levar às últimas consequências, a função integrativa inerente às ideias modernas de pátria e de nação, agora sob o espectro da ameaça da revolução social, e tendo como pano de fundo experiências norteadas por objectivos análogos: o fascismo italiano e o nazismo.

Não se deve esquecer, porém, que os jacobinos recorriam à teoria do contrato social para, revolucionariamente, justificarem que devia ser a ordem política, nascida da vontade geral, a construir a nação cívica. Ao contrário, o "novo" prometido pelo Estado Novo propunha-se modernizar o que considerava ser o melhor do passado do povo português, rejeitando a visão contratualista e voluntarista (à Herculano e à Oliveira Martins) acerca da independência política de Portugal. No entanto, também não se pode olvidar que o modelo "jacobino", enquanto tipo, inspirou, directa ou indirectamente, várias experiências históricas que, nas suas diversidades e antagonismos, estavam imbuídas de uma mesma finalidade: cimentar um tipo de Estado uno, indivisível e centralista. Por sua vez, sabe-se que os revolucionários franceses (e os jacobinos) lidaram mal com os direitos de associação e com as fragmentações provocadas pela emergência de "partidos" e de "facções", em nome da nação una e indivisível. Dir-se-ia que, por razões e objectivos antagónicos, também o pensamento conservador e contra-revolucionário contrapôs, ao dissenso, uma consensualidade justificada através da exploração de analogias com o mundo orgânico. 
Com efeito, Salazar, por razões de princípio e de facto (as características da cultura política dominante e a crise do país), opôs-se "à mentalidade partidária”, acusando-a de ser a fonte de toda a acção política fragmentária. Consequentemente, da conjugação do autoritarismo com o nacionalismo, derivava a certeza de que a fase político-partidária e parlamentarista da política estava a ser ultrapassada, pelo que a formação de uma "União Nacional" - assim se chamará ao movimento de suporte do Estado Novo nunca seria um partido. Ao contrário, teria por missão organizar a nação ${ }^{136}$ e ajudar o Estado na sua luta contra as fragmentações partidárias.

Como se sabe, esta busca de consenso e unanimismo materializou-se na perseguição das práticas políticas organizadas e dos que, em nome de um patriotismo exclusivo e homogéneo, eram tratados como inimigos internos. E se, na experiência primordial francesa, esta pretensão deflagrou no terror, no Estado Novo conduziu à ditadura e ao autoritarismo, pois as leis de excepção, nos casos de activismo e de dissensão, sobrepuseram-se aos direitos e garantias que a Constituição de 1933 também prescrevia. E tudo isto foi feito em prol da consabida divisa "Tudo pela Nação, nada contra a Nação", lema posto em vigor a partir de Abril de 1933. De qualquer modo, e para além do discurso manifesto da ideologia, ter-se-á de perguntar se a edificação de um Estado uno e autoritário não prova que, em última análise, teria de ser este a criar a nação. É que, sem a função pastoral e disciplinadora da instância política, a "nação inorgânica" não se consubstanciaria em "nação orgânica”, isto é, não passaria de nação em si a nação para si.

\section{O fascismo italiano como um cesarismo pagão}

A chamada a terreiro do caso italiano ajudar-nos-á a entender melhor o que ficou exposto ${ }^{137}$. Em vez da palavra de ordem "Tudo pela Nação, nada contra Nação", Mussolini usou outra, porque, como proclamou no célebre

\footnotetext{
${ }^{136}$ Salazar, Discursos, vol. 1, pp. 69-96.

${ }^{137}$ Para uma comparação entre os dois regimes, veja-se L. Reis Torgal, ob. cit., vol 1, pp. 56-65, 249-372.
} 
discurso de 28 de Outubro de 1925, "L'idea centrale del nostro movimento è lo Stato; lo Stato è l'organizzazione politica e juridica delle società nazionali, e si estrinsica in una serie di istituzioni di vario ordine. La nostra formula è questa: tutto nello Stato, niente al di fuori dello Stato, nulla contro lo Stato" ${ }^{38}$. Esta divisa é coerente com a orientação estatista e jurisdicionista do fascismo italiano e com o papel de vanguarda que cabia ao Estado, como instrumento mediador da vontade do Chefe e do Partido, na solificação de uma nação ainda tão mal cimentada ${ }^{139}$. É que, ao contrário das teses românticas, para os teóricos do fascismo italiano, "non è la nazione a generare lo Stato, secondo il vieccho concetto naturalistico che servi di base alla pubblicistica degli Stati nazionali nel secolo XIX. Anzi la nazioni è creata dallo Stato, che dà al popolo, consapevole della propria unità morale, una voluntà, e quindi un'effettiva esistenza"140. No seu registo próprio, o ditador italiano, sem ser um contratualista e um jacobino, via a nação em termos "construtivistas". O que se entende, já que essa perspectiva seria a que melhor se adequava a um projecto assente na liderança carismática de um Chefe e na acção permanente de um partido de massas, mobilizado para acelerar a socialização da unidade nacional italiana através do Estado, a única instância que, "come voluntà etica universale, è creatora del diritto"141, o poderia fazer. E, como se sabe, esta tese foi perfilhada por juristas italianos - e, em particular, por Alfredo Rocco ${ }^{142}$ - que não eram desconhecidos em Portugal.

A popularização da consigna de Salazar não foi inteiramente estranha à sua estratégia para demarcar a originalidade da ditadura que propugnava. É certo que reconhecia a existência de analogias entre os dois regimes, que explicita nestes termos: "a nossa Ditadura aproxima-se, evidentemente, da Ditadura fascista no reforço da autoridade, na guerra declarada a certos

\footnotetext{
138 Mussolini, Opera omnia, vol. 21, Florença, La Fenice, 1956, p. 425. Os itálicos são nossos.

${ }^{139}$ Cf. Emilio Gentile, La Via italiana al totalitarismo. Il partito e lo Stato, 3. a ed., Roma, Carocci, 2008.

${ }^{140}$ Giovanni Gentile e Benito Mussolini, "La Dottrina fascista" (www.paginadellaidee.net9... sociologia4.htm).

${ }^{141}$ Idem, ibidem.

142 Sobre os ecos deste jurista nos seus colegas portugueses, compulse-se Luís Bigotte Chorão, ob. cit., pp. 115-116, 506-512, 818-820.
} 
princípios da democracia, no seu carácter acentuadamente nacionalista, nas suas preocupações de ordem social". No entanto, imediatamente sublinhou a influência da personalidade dos respectivos líderes e do peso das tradições históricas e das condições mesológicas de cada nação na diferenciação dos regimes. Estas especificidades faziam do fascismo um fenómeno tipicamente italiano, tanto mais que, ao contrário do processo português - que caminhava para a recatolização dos valores -, tendia "para um cesarismo pagão, para um estado novo que não conhece limitações de ordem jurídica ou moral, que marcha para o seu fim, sem encontrar embaraços, nem obstáculos"143. De onde o seu frequente recurso à violência de massas, algo que contrastaria com os brandos costumes do povo português. Por tudo isso, a ditadura portuguesa seria autoritária, mas não violenta, porque se aulimitaria pelo direito e pela moral.

A referência à necessidade de se distinguir o conceito de ditadura do de cesarismo parece óbvia, sobretudo porque a grande aventura que, desde meados do século XIX, procurava edificar a unidade de Itália não deixava de evocar a memória da velha Roma. E sabia-se que Mussolini queria solidificar ainda mais aquilo que a Monarquia liberal, saída do Risorgimento, se tinha mostrado incapaz de fazer - consolidar, definitivamente, a Itália como uma nação una e indivisível -, o que somente poderia ser realizado por um Estado forte. Daí o seu programa: "unificare la Nazzione nello Stato sovrano", porque "senza lo Stato non c'è Nazione"144.

Salazar invertia os termos, a fim de melhor convencer que, sendo Portugal uma nação velha de séculos, se estava a integrar "a nação, toda a nação, no Estado”. E, com isso, também recalcava o que, na prática, não desejava confessar: o papel activo que este exerceu na criação do que se declarava ser a mera institucionalização da estrutura criada pelo viver espontâneo da nação. Isto é, se, no plano doutrinal, se dizia ter-se caminhado da nação para o Estado, a verdade é que, como o reforço do centralismo político-administrativo, e com a repressão dos adversários demoliberais e socialistas, os ditadores serviam-se do Estado para levar à prática, ainda que em nome

${ }^{143}$ In António Ferro, ob. cit., pp. 73-74. Os itálicos são nossos.

${ }^{144}$ Mussolini, La Nuova politica dell'Italia, Torino, Ed. Alpes, 1928, p. 319. 
dos "factos", os seus preconceitos ideológicos. Ora, conquanto noutro nível, também tinha sido esse o objectivo dos jacobinos: fundir o Estado na nação. E esta semelhança não escapou a integralistas como Luís Almeida Braga. Afinal, como no fascismo italiano, o regime liderado por Salazar também era jurisdicionista e estava a levar o Estado a absorver a nação. Sendo assim, não se estaria a cair numa espécie de "jacobinismo" ao contrário ${ }^{145}$ ?

145 Não deixa de comprovar a analogia aqui sugerida o facto de o velho integralista Luís de Almeida Braga qualificar a política de Hitler e Mussolini - mas com os olhos postos na do Estado Novo - como um "jacobinismo totalitário" (Luís de Almeida Braga, Espada ao sol, Lisboa, Biblioteca do Pensamento Político, 1969, pp. 193-207). 